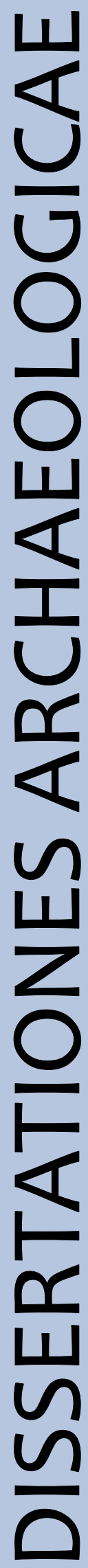

ex Instituto Archaeologico Universitatis de Rolando Eötvös nominatae
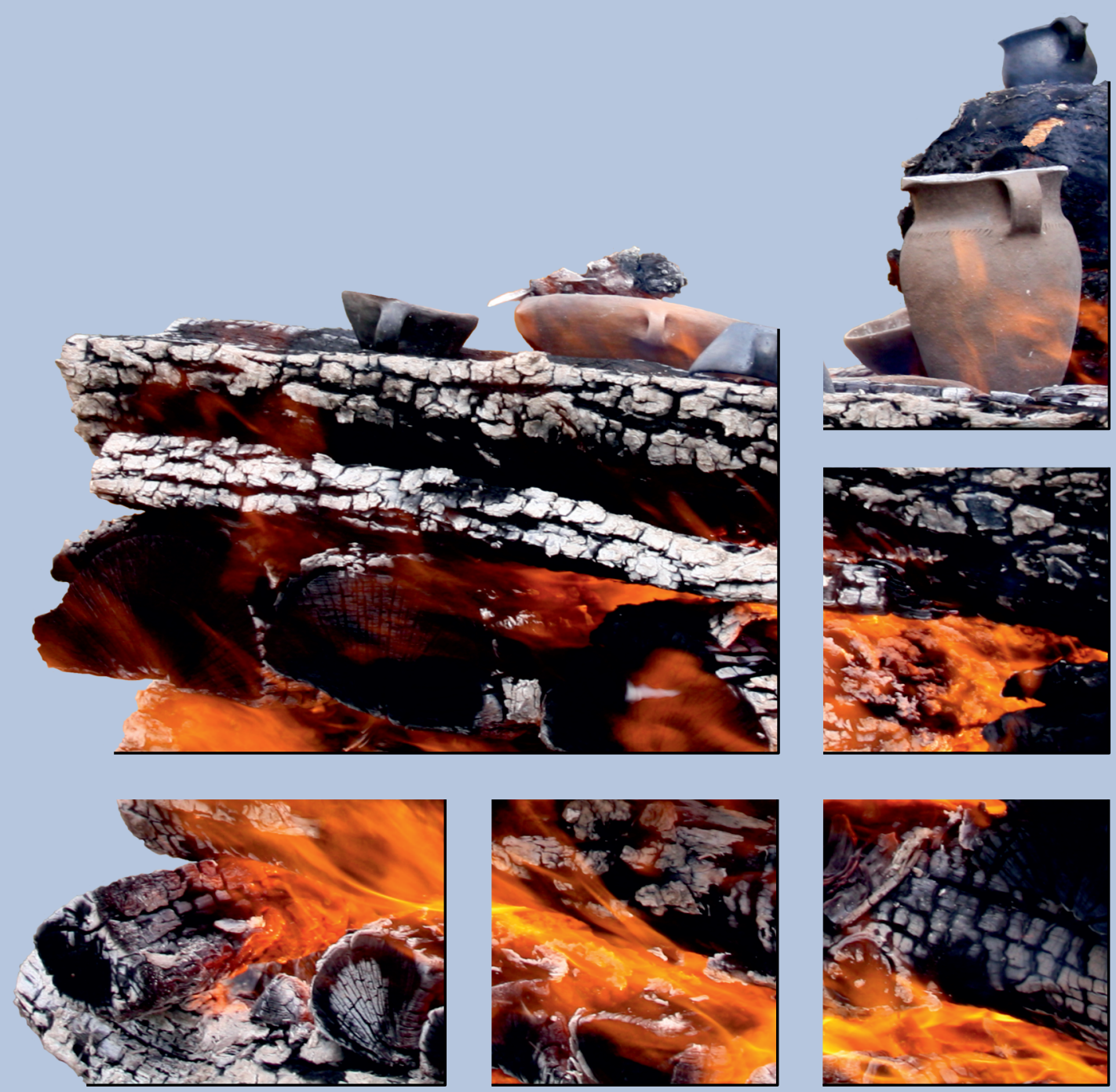

$$
\text { Ser。 3. No } 0_{0} \sigma_{0} \mid 2018
$$




\section{Dissertationes Archaeologicae ex Instituto Archaeologico}

Universitatis de Rolando Eötvös nominatae Ser. 3. No. 6.

Budapest 2018 


\section{Dissertationes Archaeologicae ex Instituto Archaeologico}

Universitatis de Rolando Eötvös nominatae Ser. 3. No. 6.

Editor-in-chief:

DÁvid BARTUS

Editorial board:

LÁsZló BARTOSIEWICZ

LÁSZLÓ BORHY

ZOLTÁN CZAJLIK

ISTVÁN FELD

GÁBOR KALLA

PÁL RACZKY

MiKLÓS SZABÓ

Tivadar Vida

Technical editor:

GÁBOR VÁcZI

Proofreading:

ZsófIA KondÉ

SzILVIA BARTUS-SzÖLLősI

Aviable online at http://dissarch.elte.hu

Contact: dissarch@btk.elte.hu

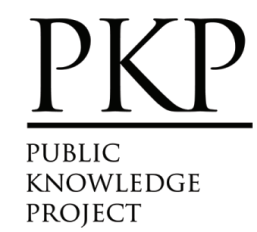

๑ E Eötvös Loránd University, Institute of Archaeological Sciences

Layout and cover design: Gábor Váczi

Budapest 2018 


\section{CONTENTS}

Zsolt Mester

In memoriam facques Tixier (1925-2018)

\section{ARTICLES}

Katalin SEBőK

On the possibilities of interpreting Neolithic pottery - Az újkökori kerámia értelmezési lehetőségeiről

András FüZESI - Pál RACZKY

Öcsöd-Kováshalom. Potscape of a Late Neolithic site in the Tisza region

Katalin SEBőK - Norbert FARAgó

Theory into practice: basic connections and stylistic affiliations of the Late Neolithic settlement at Pusztataskony-Ledence 1

Eszter Solnay

Early Copper Age Graves from Polgár-Nagy-Kasziba

László GuCsi - Nóra Szabó

Examination and possible interpretations of a Middle Bronze Age structured deposition

Kristóf FÜLÖP

Why is it so rare and random to find pyre sites? Two cremation experiments to understand the characteristics of pyre sites and their investigational possibilities

Gábor János TARBAY

"Looted Warriors" from Eastern Europe

Péter MogYoRós

Pre-Scythian burial in Tiszakürt

Szilvia JoHÁczi

A New Method in the Attribution? Attempts of the Employment of Geometric Morphometrics in the Attribution of Late Archaic Attic Lekythoi 
The Roman aqueduct of Brigetio

Lajos JuHÁsz

A republican plated denarius from Aquincum

Barbara HAJDU

Terra sigillata from the territory of the civil town of Brigetio

Krisztina HoppÁL - István VIDA - Shinatria AdHityatAma - Lu Yahui 461

'All that glitters is not Roman'. Roman coins discovered in East Java, Indonesia.

A study on new data with an overview on other coins discovered beyond India

\section{FIELD REPORTS}

Zsolt MESTER - Ferenc CSERPÁK - Norbert FARAGÓ

Preliminary report on the excavation at Andornaktálya-Marinka in 2018

Kristóf FÜLÖP - Denisa M. LÖNHARDT - Nóra SZABÓ - Gábor VÁcZI

Preliminary report on the excavation of the site Tiszakürt-Zsilke-tanya

Bence Simon - Szilvia JohÁcZI - Zita KIS

Short report on a rescue excavation of a prehistoric and Árpádian Age site near Tura

(Pest County, Hungary)

Zoltán CzAJlik - Katalin NovinszKi-Groma - László RupNIK - András BöDőcs - et al. 527

Archaeological investigations on the Süttö plateau in 2018

Dávid BARTus - László BORHY - Szilvia JoHÁczi - Emese SzÁMADó

Short report on the excavations in the legionary fortress of Brigetio (2017-2018)

Bence Simon - Szilvia JoháczI

Short report on the rescue excavations in the Roman Age Barbaricum near Abony

(Pest County, Hungary)

Szabolcs Balázs NAGY

Recent excavations at the medieval castle of Bánd 


\section{Thesis Abstracts}

Rita JENEY

Lost Collection from a Lost River: Interpreting Sir Aurel Stein's "Sarasvatī Tour" in the History of South Asian Archaeology

István VIDA

The Chronology of the Marcomannic-Sarmatian wars. The Danubian wars of Marcus Aurelius in the light of numismatics

Zsófia MASEK

Settlement History of the Middle Tisza Region in the $4^{\text {th }}-6^{\text {th }}$ centuries AD.

According to the Evaluation of the Material from Rákóczifalva-Bagi-földek 5-8-8A sites

Alpár Doвоs

Transformations of the human communities in the eastern part of the Carpathian Basin between the middle of the $5^{\text {th }}$ and $7^{\text {th }}$ century. Row-grave cemeteries in Transylvania, Partium and Banat 


\title{
On the possibilities of interpreting Neolithic pottery
}

\author{
KATALIN SebőK \\ Institute of Archaeological Sciences \\ Eötvös Loránd University \\ sebokkata@gmail.com
}

\begin{abstract}
The task of processing the multi-traditional ceramic material of the Late Neolithic settlement at PolgárCsöszhalom-dülö prenecessitated the development of a comprehensive approach by which all kinds of available information that may be detected in a ceramic object or in its find context are utilized and integrated into a closed, unbroken logical system interlinking objects and culture. This paper surveys the main topics and aspects of this theoretical structure, summarizing the author's current understanding on the possible roles and functions of Neolithic pottery.
\end{abstract}

\section{The object as a source of information}

\subsection{Information structure}

Ceramic finds incorporate basic data on shape (including size and utilitarian function), technology, and decoration ( technology, pattern structure, and pattern's elements). Besides these, an examination of the object's find context and fragmentation profile might reveal more information. These diverse data groups are variably prone to be destroyed or lost due to taphonomic processes: attached information (find context, fragmentation) represent the most sensitive groups, in contrast to encoded ones like shape and technology. As for decorations, post-firing painting and patterns made of organic materials are excessively vulnerable, while in the case of pre-firing techniques, as well as incised and applied patterns a mostly partial data loss is usually linked with a high degree of fragmentation.

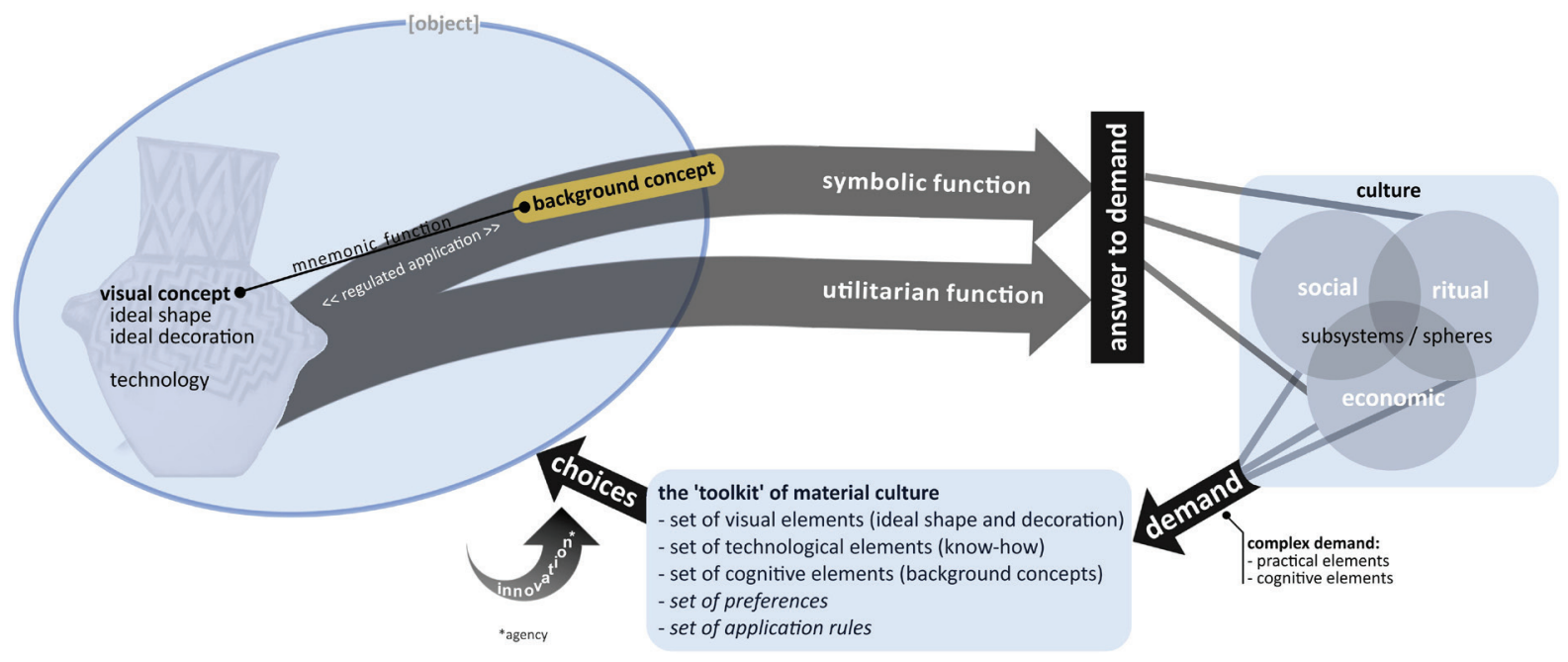

Fig. 1. Causal cycle describing the relations of object and culture. 
When looking at the relationship between an object and the culture in which it was created/used, a cycle of causality may be outlined (Fig. 1). In this cycle, every object represents a specific answer to a unique, complex demand rooting in diverse spheres of the culture. In the case of (decorated) pottery, one might suppose that the demand comprises both practical (utilitarian) and cognitive elements. The emerging demand becomes answered by utilizing the 'toolkit' of the material culture. This toolkit subsumes style, i.e., the culture's sets of visual and technological knowledge together with the regulations of their application and preferences (visual norm), and also contains cognitive elements (concepts and ideas). As a result of a row of choices from these sets basically every vessel may be interpreted as a unique combination of preset variables.

But this picture alone is incomplete: the seemingly closed cycle is capable of change and evolution, as it is eventually open at two points. First, the emerging demand itself might be an attempt to correspond to external impacts befalling the culture, which, by meeting these, reaches new states of interim equilibrium. ${ }^{1}$ And second, in the process of an object's creation it is only an option for the maker to choose from the material culture's already existing toolkit (representing, actually, Bourdieu's structure, the utilization of the doxa in accordance with the personal habitus ${ }^{2}$ ). The maker might also opt for an 'out of the box' choice (representing agency ${ }^{3}$ ), which, if proven to be successful, ultimately becomes incorporated in the culture's body of cognitive and material tradition, thus pushing the whole system toward a change.

From the object's point of view the incorporated information represents a selection of specific choices from the available sets of technological, visual (including both shape and decoration) and cognitive variables. In some cases the appearing choices might mark the presence of a mnemonic element, i.e., symbolic function.

In the case of a single object the detection of a mnemonic element present is perhaps best achieved by an analysis of the distribution of invested work and resources (where the visual part of such a circle is recognizable). In terms of design every object consists of "basic" and "extra" elements, both of which are parts of the style. Basic elements represent necessary choices and unavoidable work investment answering usually the practical part of the complex demand behind an object's creation - shape is usually a good example, but not always (e.g., anthropoor zoomorphic, skeuomorphic objects). Non-utilitarian decoration is always created using exclusively extra work (or, using D. Wengrow's term, aesthetic labour ${ }^{4}$ ), the proportion of which is sometimes prodigally high. ${ }^{5}$ Aesthetic labour always represents quality work, as it prerequisites that the maker has the necessary skills and masters the relevant know-how, and is familiar with the related cognitive elements, the rules of application, and the cultural preferences. The presence of a background concept, a certain cognitive element behind a visual or material solution may only be detected on the type level, appearing on particular examples as a recurring (set of) design element(s) arranged always according to similar regularities. The background concept might be connected with any part of the design as well as with the image of the object as a whole, and multiple concepts serving various mnemonic functions might be connected

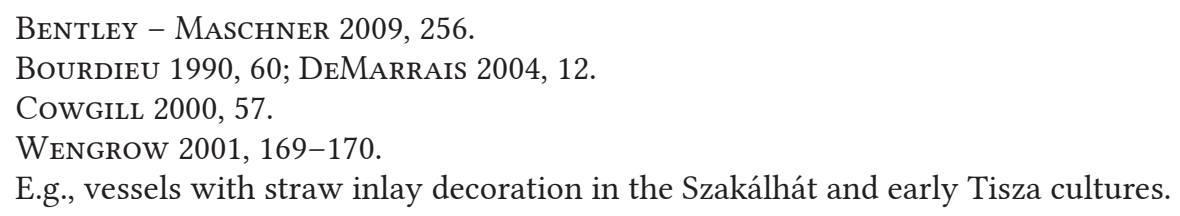


with diverse parts of the design. The visual element, the background concept and their mnemonic function form the concept circuit (Fig. 2), which must be considered entirely as a part of the set of information encoded in the object in the course of its creation. The concept circuit makes it possible for material objects to perform a symbolic function and to serve as part of the culture's external symbolic storage. ${ }^{6}$ The key element is the background concept, which is practically a primary, independent meaning of the visual elements bearing the mnemonic function.

\section{közvetlen képzetkör / concept circuit}

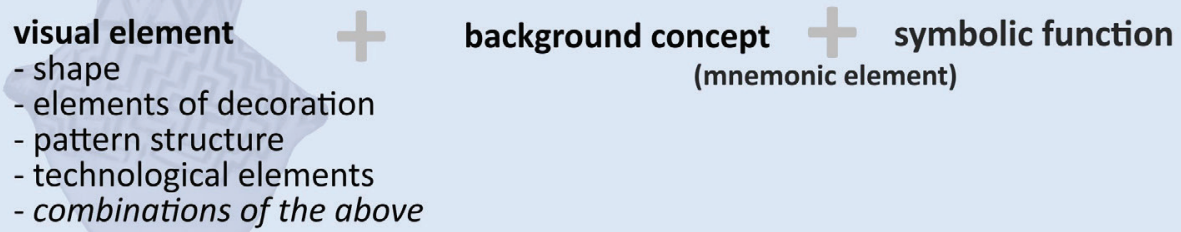

visual element
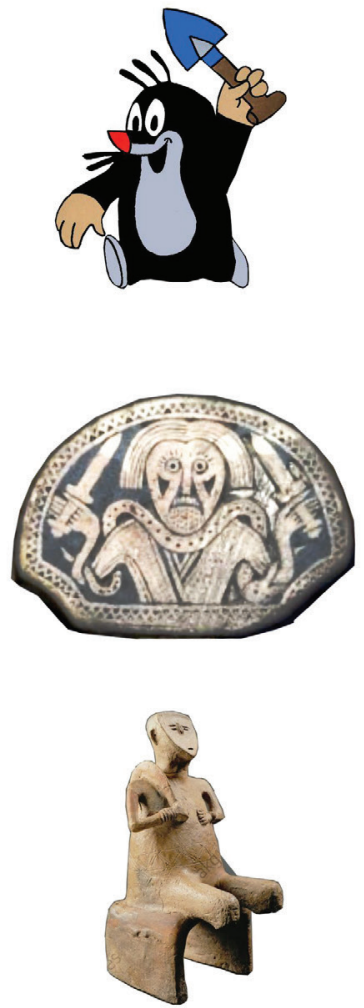

background concept

(primary meaning

of the image)

'Little Mole'

- ideal world

- positive hero

- small child

- adventures

\section{Odin}

- warrior/death (weapons, wolves)

- wise (one-eyed, spears, birds)

- lord of worlds (snake)

$$
\begin{aligned}
& \text { - transmission of behavioral } \\
& \text { norms and ecpectations } \\
& \text { - transmission of social norms } \\
& \text { and expectations }
\end{aligned}
$$

\section{symbolic function}

- explaining identity / origin

- transmission of social structure

- transmission of behavioral norms and expectations - explanatory function

Fig. 2. The structure of the concept circuit with examples. Representation from the reader's cultural environment: the Little Mole; a representation from an other culture supported by written sources: Odin's depiction on a buckle-belt from the Avar Period cemetery of Kölked-Feketekapu B, Grave no. 85 (after VÁGÓ 2015, VIII. 56); a prehistoric representation, (interpreted earlier as) the 'Sickle God' from Szegvár-Tüzköves (after MaKKay 1978, 2. kép). 


\subsection{The accessibility of information (Fig. 3)}

When looking at an object, in terms of information accessibility the negative end is represented by the actual content of the cognitive elements. As both the primary meaning of the background concept and the symbolic function are culturally bound, these cannot be fully grasped by an observer not sharing the very same cultural background. The positive end is represented by the easily readable technological and visual elements, and by a part of the regulations of their application. An in-between state may only be grasped on the type level. The elements ordered here are only partially cognizable: their presence might be proven, but their content is not accessible. This is the case with parts of the visual elements' application regulation, the mnemonic function, the symbolic function, and the relation between the object and diverse spheres or subsystems of the culture.

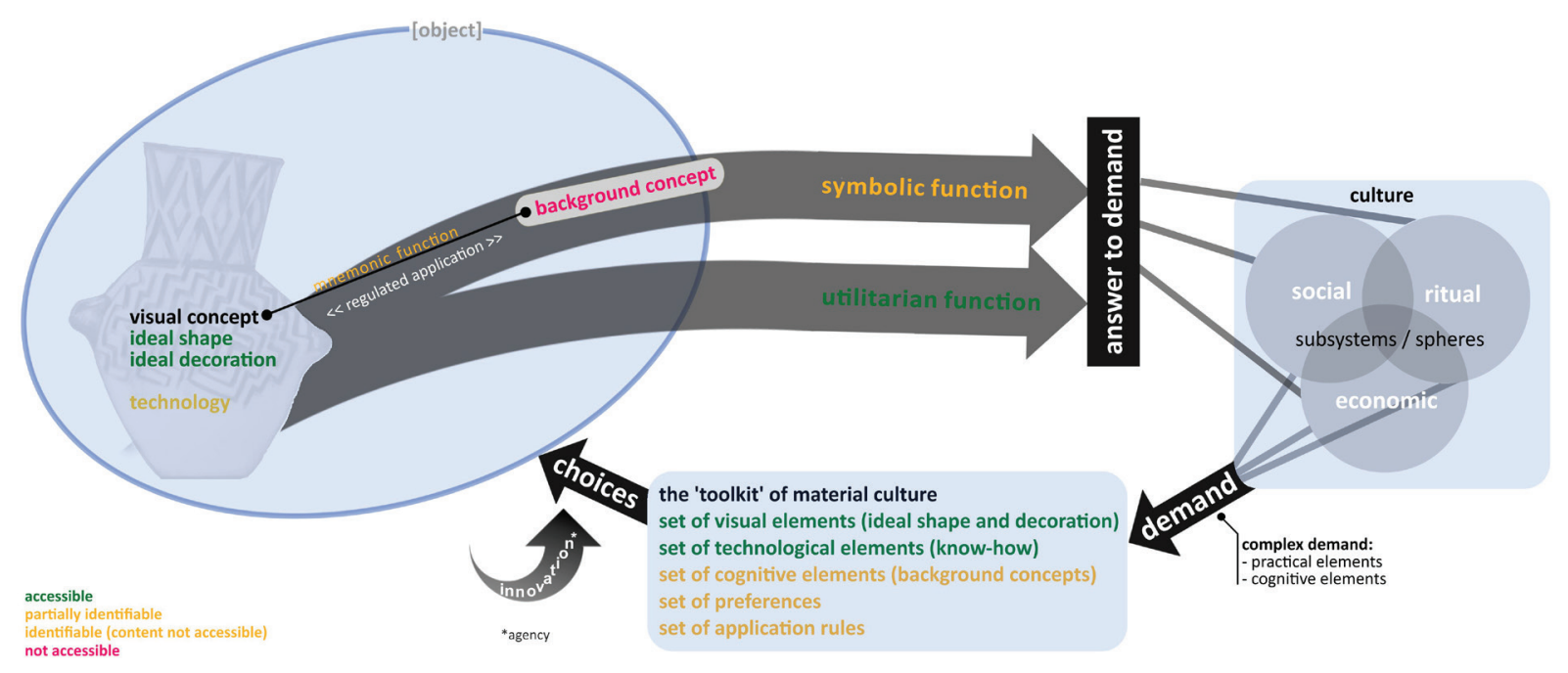

Fig. 3. Availability of the informations incorporated in, or related to an object.

The 'behaviour' of a type gives away information on the presence of a concept circuit behind. The visual element itself does not have the capability to withstand intentional alteration or copy degradation, but it becomes retained by a visual canon that links it with the background concept. The more complex a circuit's visual part, the more prone it is to changes. When the circuit breaks as a result of the fading or change of the background concept, or a partial or complete loss of the mnemonic function, the visual element becomes left alone and usually starts to degrade. This phenomenon is especially frequent in cultural stress situations (e.g. in the archaeological record of settlements in cultural interference areas), where multiple symbolic systems are at work simultaneously.

\subsection{The significance of the production background}

The symbolic function of an object is not served by the object itself. It becomes realized by the relation of the object and the (end) user. Therefore it is crucial when and how, during the object's life course, their connection becomes established. An analysis of the production background might provide a way to learn about this.

The production can be either non-specialized, or partially, or fully specialized (Fig. 4). When the production is non-specialized, the maker and the user are quite often the same (or are engaged in a continuous communication), thus the user is fully involved in the formation process, 

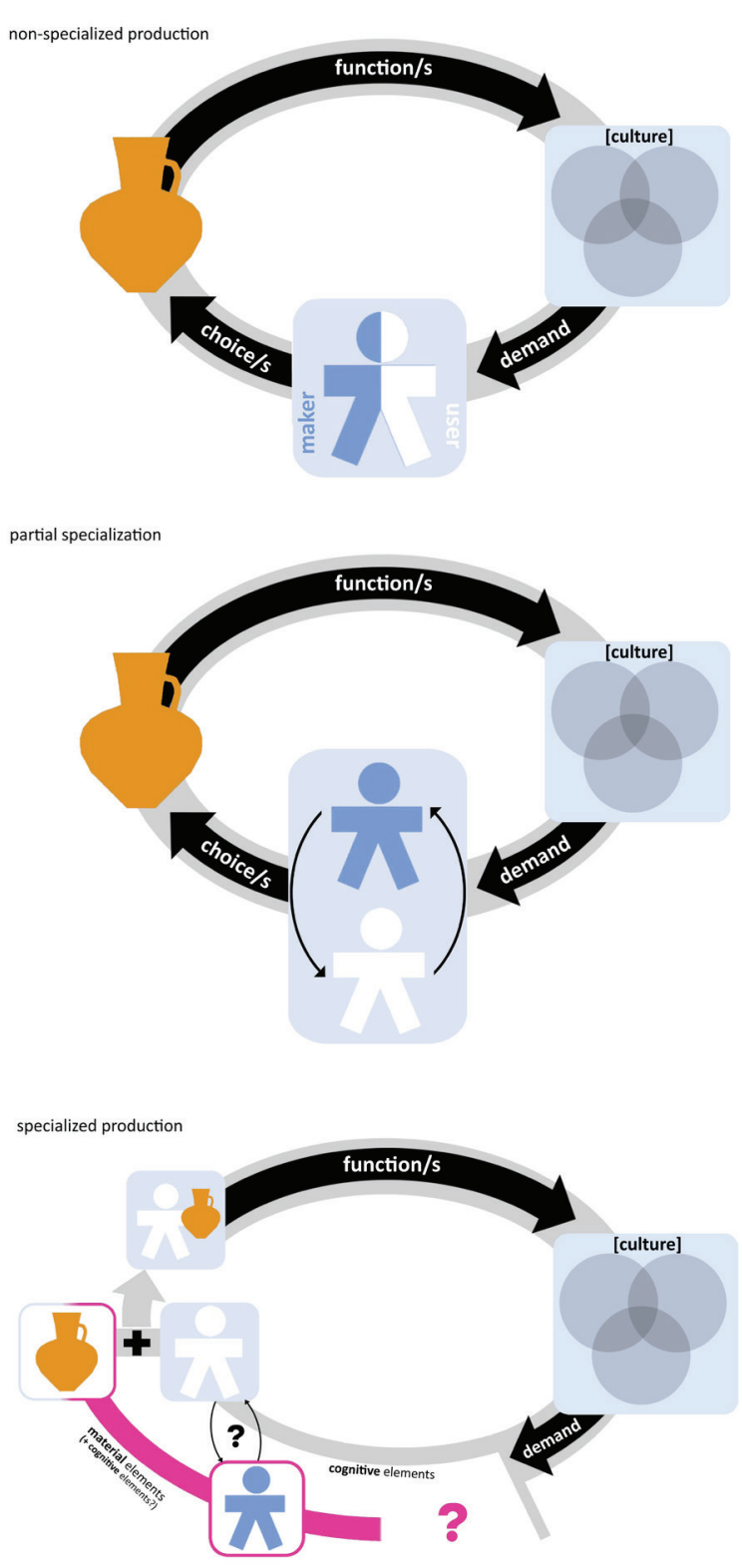

Fig. 4. The role of the production background.

and can shape the object exactly according to his/her actual demands (and knowledge and skills, when they are the same). The end product thus will be 'tailor-made', and the visual part of the concept circuit can entirely serve the cognitive part (as the exact concept and the design work together from the beginning of the production). In the case of non-specialized production factors other than economy may play a role, allowing non-professionals to participate in the process of creation. As these people are not necessarily chosen by their manual skills (e.g. the right to make a certain object can also be linked with a specified social position), the quality of the products might vary in a wider range. When the maker is a non-professional, it is much more likely that the end products, despite being created for similar purposes and according to the same rules, will be unique in some fine details either unintended or on purpose to distinguish every single specimen of the type. Also, for the very same reasons, the amount and/or proportion of invested extra work is the highest with vessels produced this way. Non-specialized production of decorated objects or those with symbolic content may also has a social aspect, as it involves a reproduction (or rather, recreation) of the ideas, concepts, and regulations of the culture, thus providing a possibility of social contest, and for the maker a chance to improve on his/her social image by creating an extrasomatic, steady representation of his/her knowledge and skills.

Partially and fully specialized production usually means (open or symbolic) market production, where the basis of production is, in the end, mainly or exclusively economic. When the production of something is specialized, in terms of (cultural, social or cognitive) demand the end product is 'off the shelf' at best. This means that even if the object (vessel) was created in the very same cultural environment where it was intended to be used, thus the production follows the 'user' culture's basic regulation of (ceramic) production, the fine details (shape and decoration in this case) do not necessarily fit to or reflect exactly the demands of the end user (as he/she is excluded from the formation process). From the cognitive element's point of view, in this case the concept circuit's cognitive elements may need to be altered, fine-tuned according to already set design elements, as the background concept related to a specific symbolic function and the design only meet first after production (especially by 
fully specialized production, where the object is not necessarily created in the same cultural environment where it was intended to be used). When the production is specialized to any extent, the number and proportion of series of exact copies inevitably grows, leading to the appearance of 'style districts', marking, in most of the cases, the distribution area of a certain maker or a workshop. Also, in the long run, one must calculate up to a uniformization and simplification of some design elements (concerning especially the fine details of the decoration) as a result of a tendency to minimize work investment. Another characteristic phenomenon accompanying the process can be a gradual distortion of the related customs and background ideas. ${ }^{7}$

It is easy to see how the production background might affect the formation and spread of canonized decoration systems. Visual canons in large areas and/or for a longer periods of time can only exist with concepts or ideas behind them, as the more complex a visual element is, the less it can withstand occasional alterations and copy degradation by itself. By partially or fully specialized production the spread of a visual canon happens first on the visual level, and it is not necessarily accompanied by the originally related customs and/ or concepts (if there are any). When the formation of the (first) symbolic function, i.e., the precise initial relation between the cognitive and visual elements of the circuit only becomes completed after the object's creation, these elements may get separated more easily as the type spreads through space or time. In this case an observed spread of a visual element cannot be simply equalled with that of the full circuit, but one must include the possibility of a transformation of the cognitive part to suit the possibly different demands (symbolic functions), customs and cognitive sets of the recipient community. This results in a possible cognitive heterogeneity behind a visual element.

When the production is non-specialized, it is much harder for a visual canon to form and spread, because this must happen first or at least simultaneously on the cognitive level (as the cognitive element is already active during the object's creation). This also shows the limitations of observability: the presence of a mnemonic function is only to be detected by archaeological methods if it is directly linked to a visual element as early as during the object's formation. ${ }^{8}$ Find context in most of the cases (besides intentional deposition) means that the object

7 At least in the Neolithic of the study area. Professional production's aim can also be the creation of elaborate, top quality, often unique luxury objects, with makers mastering unmatched skills and/or using special infrastructure, but the emergence of such workshops prenecessitates an elite with both a demand for such products, and a sufficient purchasing power.

8 Reality is more complex, as always: rarely, under the right circumstances cognitive elements can also spread without the visual part of the circle. This is the case with the Late Neolithic burials at PusztataskonyLedence 1, where the adaptation of a foreign custom (application of Lengyel type funerary vessel sets to the burials) was observed, but with using local type variants with similar utilitarian functions instead of adapting the original (Lengyel) ones. (Sево̋к 2012, 114.). On the object level this phenomenon calls for diverse possibilities of interpretation: either the Lengyel vessel types had exact meanings inside their original cultural context, which had to be 'translated' to the adaptor's symbolic language during the process by choosing local types with similar meanings; or, the individual types (at least in a funerary context) themselves did not incorporate relevant meaning, i.e., they did not possess a part of the funerary vessel set's meaning (while in this context any other kind of symbolic meaning is irrelevant). Therefore it must be underlined that from the symbolic meaning's point of view the object itself is secondary in this case, as it is not connected with a single object but becomes realized by the actual set and its find context. Also, these vessels (at least in Pusztataskony) appear in a secondary role, which, when obtained, did not necessitate their physical alteration in any case but one (see below). As the last symbolic function is not present during the object's creation, the production background in this case is irrelevant. 
was disposed of, i.e. it does not reflect an active state of use. Under the right circumstances it may have the capability to provide information on an object's non-utilitarian function, but that is always restricted, as only concerns the last active function.

\section{How it works: the vessel as a medium of social signaling}

To describe how a vessel can meet non-practical cultural demands one must analyze its possible roles and functions. From a nonverbal communication's point of view, as an element of material culture every object has a utilitarian and a signal function.

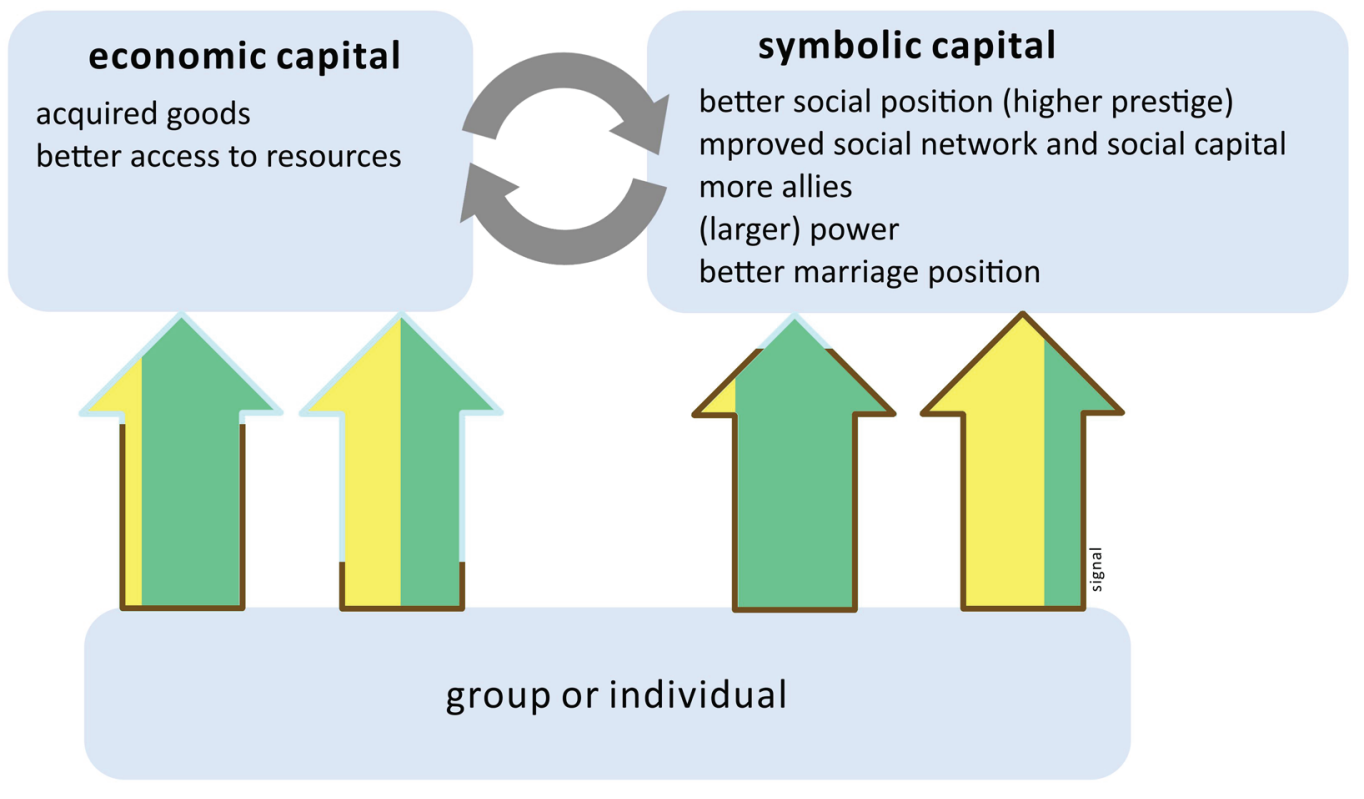

subsistence-related signal ingredients

inconstant signal ingredients (events)

symbolic signal ingredients

persistent signal ingredients (display)

Fig. 5. Diagram displaying the basic structure of social signaling's working mechanism: the signaller (individual or group) accumulates interconvertible economic and symbolic capitals by transmitting diverse signals of varying composition containing both inconstant and permanent elements (after Bliege BIRD - SMITH 2005). This enables the signaller to constantly reposition itself in society.

Social signaling is the most important field of interaction between individuals and groups, allowing them to exteriorize and display their social image, thus ensuring an independent, constant presence in the cognitive, social or physical space (Fig. 5). Just like today, in the Neolithic world anything altered (directly or indirectly) or created by humans had the capacity to become a signal: the elements of the built environment, the (mobile) objects and the elements of attire, as well as rituals (specified sequences of movements and actions acting as practical modules of the cognitive tradition). Social signaling is a powerful tool to constantly recreate social reality. ${ }^{9}$

The character of an object's signal function may be revealed by taking account of all the detectable signal ingredients (Fig. 6). These can be depletable or non-depletable, and may be ordered into three groups: cognitive content (applied elements of the cognitive tradition),

9 TOREN 1999, 18. 
invested work and used skills, and built-in resources (e.g. raw materials, previously acquired goods, stamina). ${ }^{10}$ The signal's constitution (the mobility and lifespan of the ingredients) determines its possible functions and roles in the symbolic communication. Diverse signals may be linked with different levels of social grouping from the sides of both the signaller and the receiver (e.g. the signal functions as well as the intended circle of recipients of an enclosure and a decorated cup differ fundamentally).

\section{SIGNAL INGREDIENTS}

\begin{tabular}{|c|c|}
\hline $\begin{array}{l}\qquad \begin{array}{l}\text { material } \\
\text { (accumulated goods) }\end{array} \\
\text { objects } \\
\text { expensive / hard-to-access materials } \\
\text { valuable property (e.g. livestock) }\end{array}$ & $\begin{array}{l}\text { immaterial } \\
\quad \text { natural } \\
\text { (manual) skills } \\
\text { stamina } \\
\text { work }\end{array}$ \\
\hline & $\begin{array}{l}\text { learned } \\
\text { cultural knowledge: cognitive and techno- } \\
\text { logical tradition; rules of application, } \\
\text { preferences } \\
\text { social regulation: rights, taboos }\end{array}$ \\
\hline $\begin{array}{l}\text { leting resources } \\
\text { wable / non-depleting resources }\end{array}$ & $\begin{array}{l}\text { display of rights and possibilities } \\
\text { connected with the actual social position }\end{array}$ \\
\hline
\end{tabular}

Fig. 6. Signal ingredients (partially after BLIEGE BIRD - SMITH 2005).

When a signal contains a large amount and/or proportion of work and/or depletable resources, then cost, more precisely the display of the signaller's (economic) potential is an essential element of its mechanism of action (costly signaling). This is the most reliable, therefore most widespread signal type as costly ingredients are usually hard or impossible to fake. Due to its character, this is also the signal type the traits of which are the most easily detectable using archaeological methods. Decorated vessels also count as costly signals, where the main source of signal value usually is aesthetic labour. ${ }^{11}$ In the case of painted vessels, the applied materials (by their symbolic or market value) may also add greatly to the signal value.

Several observations suggest that pottery during the second half of the Neolithic is mainly used in everyday symbolic communication (unlike, e.g., enclosures or burials). Ceramic objects appear frequently; the basic materials of potterymaking are easily available, and clay itself is a fictile but a quite durable medium; and also, the amount of basic and extra work and other efforts required to make a vessel usually stay in the individual's range (except for firing, which probably can be carried out more effectively in a small group's cooperation). Both the practical function and the lifespan of the vessel types in an inventory vary, leaving us with basically three main functional type groups: containers, cookware, and representative vessels ( 'tableware'). Usually, cookware plays the smallest part (if any) in symbolic communication, as the vessels' lifespan is shorter, and their use is the least linked with the actual space of social interaction. Containers might have a relatively long life, and they are frequently immobile

10 Bliege Bird - SMith 2005, 228-232.

11 Of the recognizable ones. There can always be ingredients of original value that cannot be detected - e.g., clay or water from a special source with symbolic value. 
due to their size or structure, therefore - and also by the value of their content - they can be fit to transmit a message for long (in this case the signaller might be the household or other - creator, user - group). The main field of signaling is representative vessels.

This threefold division, together with a heavily unbalanced distribution of aesthetic labour amongst the types is well detectable in inventories of the Linear Pottery tradition, where the majority of the vessel types is barely decorated (except for simple additions, usually of utilitarian character, e.g. to enhance grip or to raise surface), while large amounts of aesthetic labour seem to be assigned to a few dedicated types (signature types). The signal function of the signature types can serve diverse purposes. It can be connected with the expression of prestige, ${ }^{12}$ social position, ${ }^{13}$ various forms of cultural or group identity, ${ }^{14}$ or the abstract set of ideas related to the ritual sphere. ${ }^{15}$ Decorated pottery is a significant medium of social signaling in the Middle and Late Neolithic of the Carpathian Basin. This practice of symbolic communication only wears out gradually, around the dawn of the Copper Age, because of a partial loss of content due to fundamental changes in the way of life, and a shift to new, emerging mediums (e.g. copper).$^{16}$

\section{The life of objects}

An exact relation between object and culture is set initially during the object's creation (or by the first use, if the production is semi- or fully specialized). But during its life course, every object might gain new, temporary or permanent functions, by which it can establish new connections with diverse spheres or subsystems of the culture.

Not every non-utilitarian function of an object is always active. Some of them are incorporated but latent, manifesting only in specific situations. This seems to be the case with the vessel depot unearthed in Feature 272 (a well) at Polgár-Csőszhalom-dülő. ${ }^{17}$ Despite the abundance of the vessel types in the settlement's material, only a few local types were used for deposition (Fig. 7.1-6; closed vessels with shifting cross-section and jug variants). The deposited examples did not differ at any point from the rest of the types' appearances in the settlement material. This suggests that the content or function making these vessels fit to be included in the ritual by which the depot was created must already have been an integer part of the types' set of background concepts and ideas, but only became activated for that specific occasion. One must suppose similar factors to be at work in the case of the 'everyday' vessels which become grave goods unaltered, a custom practiced e.g. by the Linear Pottery Culture groups and the Lengyel culture.

Occasionally the change in function is accompanied by a physical alteration of the object. In a burial of the Tisza culture unearthed at Pusztataskony-Ledence 1 a flowerpot-shaped vessel was placed in the grave. ${ }^{18}$ Its original decoration, a rich incised geometric pattern enhanced by red and black painting had been coated in white at some point before the vessel was put

12 Lichardus - Lichardus-ItTEN 1997, 207-210.

13 Siklósi 2004, 4-6; ZALAI-GAÁl 2001, 46; ZALAI-GAÁL 2002, 74; ZALAI-GAÁL 2008, 269; ZALAI-GAÁL $2010,76$.

14 Sево̋к 2009, 14-16; Seвőк 2012, 114; ZeEb-LANZ 2003, 35; ZeEb-LANZ 2006, 84-95, Abb. 12.

15 Kalicz 1998, 101.

16 SiKLósi 2013, 222-223.

17 Sево̋к et al. 2013, 35, 47, 14. kép 1-3.

18 RACZKY - ANDERS 2011, 199-201. 

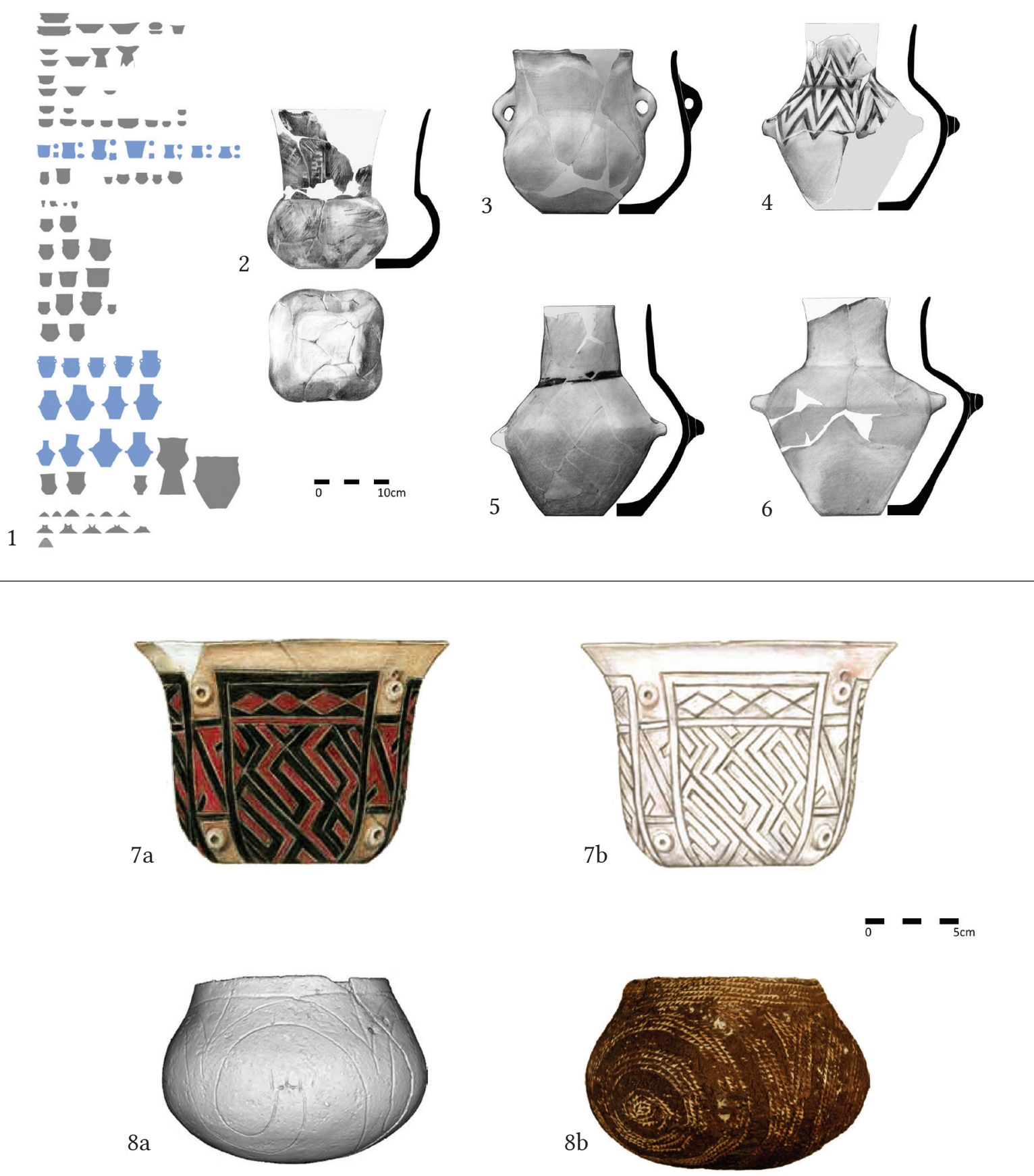

Fig. 7. Examples of changes of function through a vessel's life. 1-6 - the change of function is not accompanied by a physical alteration of the vessels, but only by a change of the find context in the vessel depot found in Feature 272 (a well) at Polgár-Csőszhalom-dűlő. 1 - ceramic inventory of the horizontal settlement, the types appearing in the well's vessel depot are marked by blue, 2-6 - examples of the vessel types appearing in the well's vessel depot (after SввőK et al. 2013, 4. kép 3, 7. kép 3, 8. kép 5, 9. kép 10,12. kép 9, 15. kép). 7-8 - the change of function is accompanied by a physical alteration of the vessel as well as by a change of the archaeological context. 7- 'textile' decorated vessel from Feature 1-65, a burial of the Tisza culture, at Pusztataskony-Ledence 1. The vessel's incised geometric decoration, originally enhanced by red and black painting (7a) was coated in white preceding its application as grave good, probably as part of the funerary process (after RACZKY - ANDERS 2011, Fig. 3). 8 - a tar coated vessel with reed inlay mosaic decoration from the Early Neolithic well of Skeunitz-Altscherbitz. The incised decoration (8a) was covered by a layer of tar coat and elaborate mosaic work (8b) before the wessel was deposited in the well (after Elburg 2013, Fig. 11a-b). 
into the grave, possibly as part of the funerary process (Fig. 7.7). As the custom of fitting the burials with a funerary vessel set is of foreign origin (adapted from the Lengyel culture) in the settlement, the signal content of the original textile decoration could not have been a part of the related cognitive background, and, as a disturbing element in this context, ${ }^{19}$ it probably must have been neutralized by overwriting it with a new message. One of the small tar coated vessels with a straw inlay decoration in the approximately coeval well of Skeunitz-Altscherbitz (Fig. 7.8) must be a result of a similar process. In this case, the original decoration was an incised pattern, characteristic of the Šarka group. ${ }^{20}$

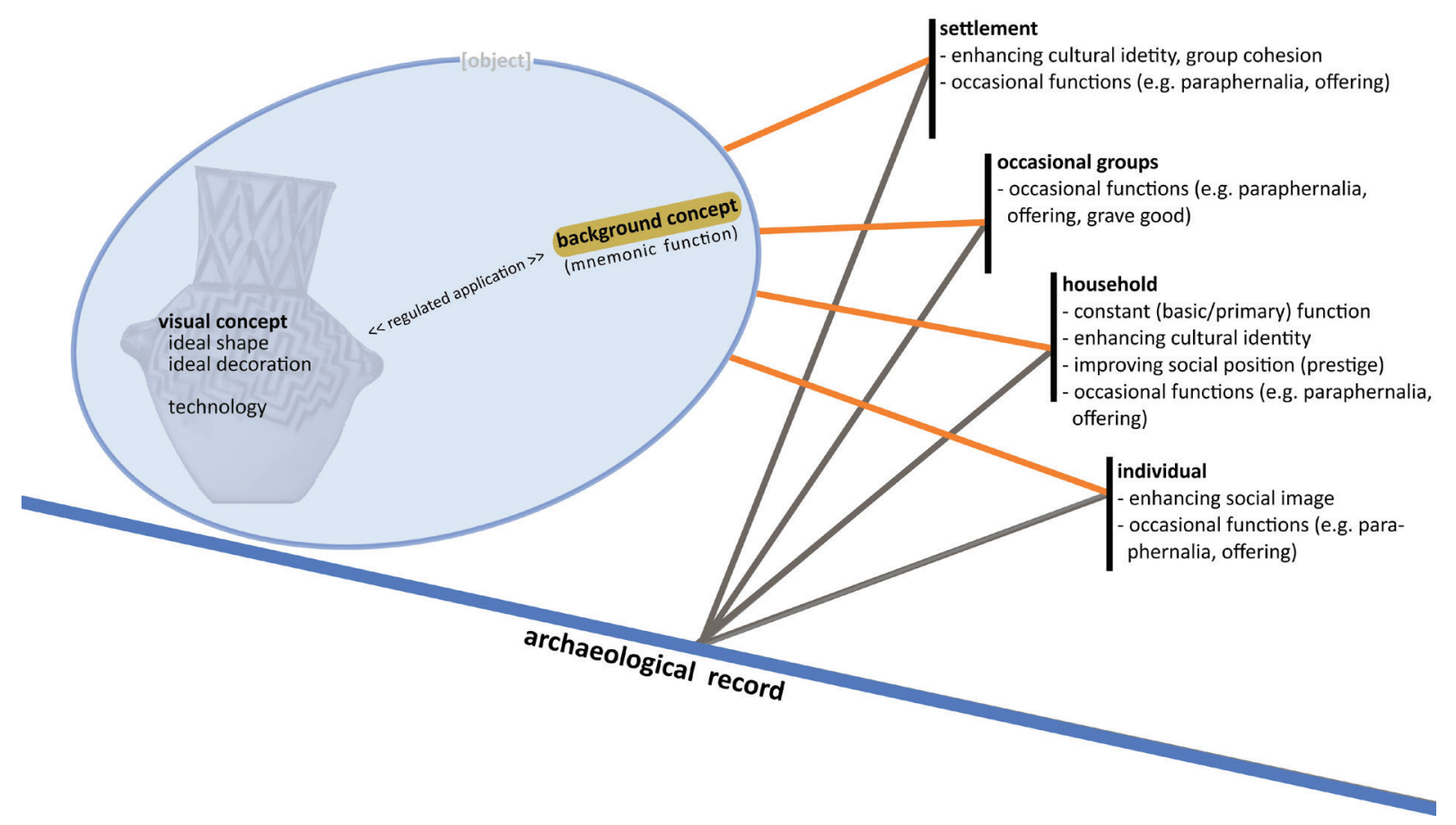

Fig. 8. Possible relations of the object and the user community based on the social modules as learned from the archaeological material of Polgár-Csőszhalom-dúlő. Occasional groups may refer to intra-settlement groups as well as to ones incorporating people from a number of nearby settlements (RACZKy - SeBőK 2014, 63).

Every object can maintain both temporary and permanent connections at the same time with the cognitive realm as well as with diverse group levels of the community (Fig. 8). The importance of these connections fluctuates through time. As there are too many potential variables on both ends, in the current study this relation is explicated using the social model of the Late Neolithic settlement at Polgár-Csőszhalom-dűlő. The social modules in this case are the individual, the household, the community, and occasional groupings of diverse size and duration, the latter involving a part of the settlement's population or involving lesser groups from several nearby settlements. As the local technological background and the characteristics of the ceramic sample series (i.e. examples of a type) refer to non-specialized production, to make a (signature) vessel from the individual's (maker's) point of view here might be seen as a possibility to create a permanent extrasomatic representation and enhance social image (perhaps ameliorating the household's social position as well). Currently 
it is not possible to link precisely the more complex social modules with exact cognitive functions, but the transmission of messages around diverse topics through style may be reasonably presumed, like a probably permanent expression of group identity (using both emblemic and assertive messages), as well as temporarily active contents connected with the ritual sphere (e.g. feasting and other rituals).

Nonetheless, it must be kept in mind that the archaeological record does not preserve the life trajectories of vessels (only the final stage), and also that these ultimate episodes appear intermixed. The last active functions are only detectable by archaeological methods if they 'leave a trace', which can be (compared to other examples of the type) an unusual find context or fragmentation profile, or (compared to other sets in the site) an extraordinary vessel set composition.

\section{Acknowledgements}

The research behind the present study became possible due to the financial support of the National Research, Development and Innovation Office. The analysis of the ceramic material of Polgár-Csőszalom was carried out as part of the project NK 101024 (led by Pál Raczky), while PD 116711 aimed the processing of the archaeological record of Pusztataskony-Ledence 1. I would like to express gratitude to Pál Raczky for the possibility to work with the Late Neolithic ceramic material from Polgár-Csőszhalom. I am indebted to Zsófia Kondé for her help with the proofreading of the manuscript. 


\section{Az újkőkori kerámia értelmezési lehetőségeiről}

\section{Bevezetés}

Amikor 2009-ben hirtelen közelivé vált a lehetőség, hogy a Polgár-Csőszhalom feltárásaiból származó kerámiaanyagot önálló projekt keretében feldolgozzuk, nyilvánvaló volt, hogy a munkát az elméleti háttér kidolgozásával kell kezdeni. ${ }^{21}$ Ezt a feldolgozásra váró leletanyag mennyisége - mindent összevetve közel félmillió töredék - mellett annak látszólagos kulturális sokszínűsége is szükségessé tette; ilyen feltételekkel még az adatfelvétel megkezdése előtt be kellett határolni a feltehető és releváns kérdések körét. E kérdések a kerámia közösségen belüli szerepe, e tárgyak esetleges kognitív funkciói, készítésük és használatuk sajátosságai, illetve a rajtuk keresztül megfigyelhető (régészeti) kulturális keveredés mintázatai témái köré csoportosultak; így a kutatás mögött meghúzódó megközelítés elméleti struktúrájának kidolgozásánál is elsősorban ezekre fókuszáltunk, apránként felépítve egy logikai rendszert, melyben az egyes elemek - pontos kérdések, választások, lehetőségek - az alapoktól kezdve levezethetőek és indokolhatóak. Az alábbi írásban ezt a minden edény mögött kirajzolódó információs struktúrát vázolom fel; célom az eddig felismert és rendszerbe illesztett szempontok, tényezők, erővonalak és korlátok felsorolása és összefüggéseik, viszonyaik tisztázása. Ezáltal egy, a tárgyhoz kapcsolódó összes elérhető információt figyelembe vevő, logikailag zárt interpretációs megközelítés kialakításához szeretnék hozzájárulni, remélve, hogy a felvázolt, korántsem teljes kép egy, a hazai kutatásban meginduló módszertani párbeszéd egyik kiindulópontja lehet.

\section{A tárgy mint információforrás}

\subsection{A tárgy információs struktúrája}

Elsőként azt érdemes végiggondolni, milyen típusú információk kapcsolódnak egy tárgyhoz, és mi módon. Ezek egy neolit edény esetében a forma (ide sorolható még a méret és az elsődleges vagy használati funkció is); a technológia (készítés- és díszítéstechnológia); a díszítés (díszítéstechnológia, mintaszerkezet és mintaelemek); valamint a fragmentáció és a leletkontextus. Ezek az információcsoportok változó mértékben érzékenyek a leletképződés és a régészeti adatgyűjtés során fellépő tafonómiai hatásokra. A tárgyhoz közvetetten kapcsolódó információkat értelemszerűen igen könnyű elveszíteni, ezért a kontextusra vonatkozó és a fragmentációs adatok a legsérülékenyebbek. Más a helyzet a tárgyba kódolt információkkal: ezek esetében az információvesztés mértékére az adott tárgyon megjelenő választások is hatással vannak. Információvesztés azonban gyakorlatilag minden csoportot érinthet. A készítéstechnológiai adatok a legnehezebben elveszthetőek (pl. a felületek sérülésével); a díszítéstechnológia esetében érzékenység tekintetében a pasztózus festés és a szerves anyagú díszítések emelkednek ki. A plasztikus, karcolt, illetve ráégetett díszítések és a forma esetében leginkább a tárgy erős töredezettsége járhat (többnyire részleges) információvesztéssel.

A tárgyat mint a benne kódolt, valamint hozzá kapcsolódó információk összességét a létrehozó kultúra viszonylatában szemlélve zárt ok-okozati lánc rajzolódik ki (1. kép). Ebben

21 Jelen tanulmány az Őskoros Kutatók VIII. Összejövetelén, 2013. 10. 17-én a debreceni Déri Múzeumban „Közelítő körök: a neolitikus kerámia értelmezési lehetőségeiről” címmel elhangzott előadás jelentősen átírt és kibővített átirata. 
a viszonyrendszerben a tárgy az adott kultúra különféle szféráiban vagy alrendszereiben létrejövő, összetett, egyedileg felmerülő igényre adott eseti válaszként értelmezhető. Mivel jelen esetben (részint díszített) kerámiaedényekből indulunk ki, feltételezhetjük, hogy az igénynek vannak a funkcionális mellett kognitív (például rituális, vagy az identitás valamely rétegéhez, esetleg a társadalmi pozíció vagy a vagyoni helyzet kifejezéséhez kapcsolódó) elemei is. Azt a csatornát, melyen keresztül a felmerülő igény kielégítése, azaz a létrejövő tárgy paramétereinek meghatározása megtörténik, az anyagi kultúrát meghatározó eszköz- és ismeretkészlet jelenti. Ez a készlet tartalmazza egyrészt a kultúra vizuális és technológiai ismereteinek választékát, másrészt az azok felhasználását behatároló szabályrendszert és a preferenciák készletét (vizuális normák), azaz összegezve a stílus elemeit; harmadrészt pedig kognitív elemeket (képzetek és koncepciók). Ebből a készletből kerül kiválasztásra a különféle elemek azon eseti összeállítása, melyek végül megjelennek a tárgyban, illetve a tárgyon.

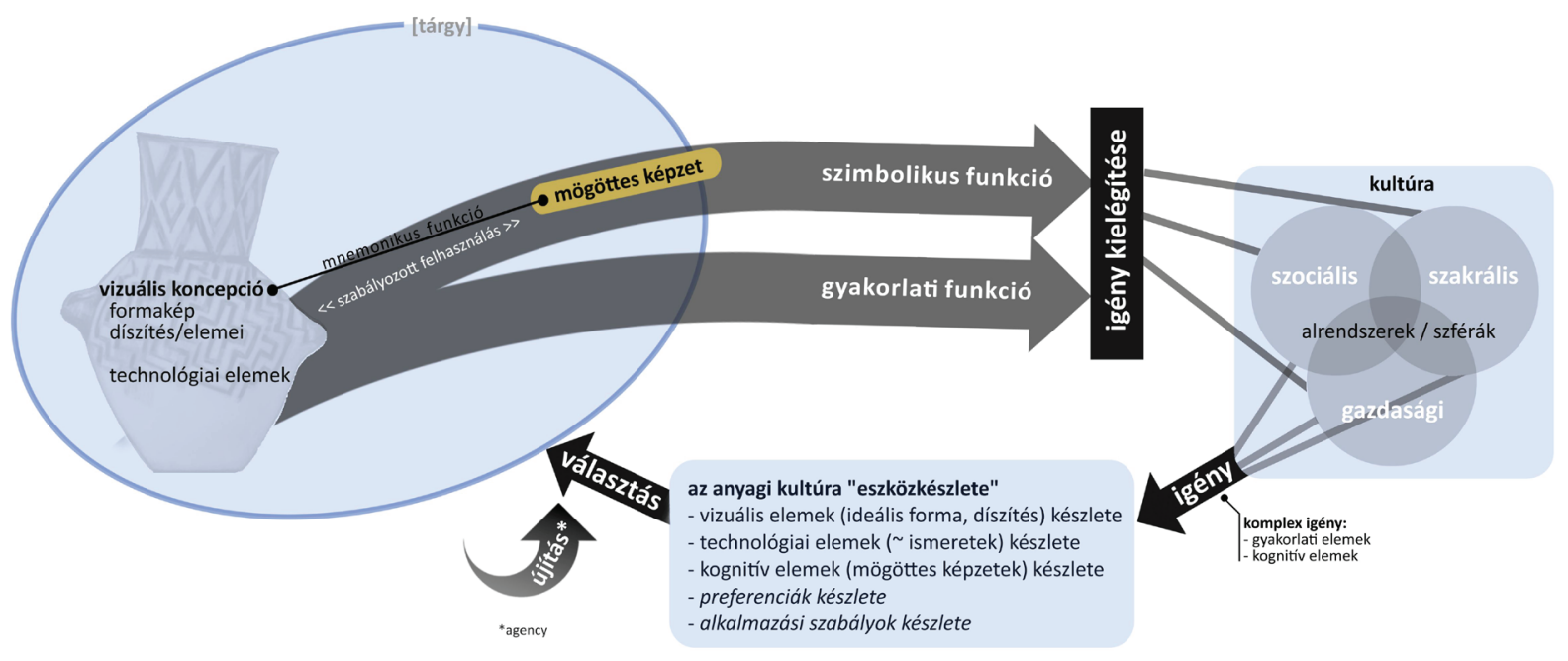

1. kép. A tárgy és a beágyazó kultúra viszonyát leíró ok-okozati kör.

A felvázolt ciklikus rendszer látszólagos zártsága mellett is képes lenne a fejlődésre, hiszen egyik sarokpontja tulajdonképpen nyitott (a beágyazó kultúrában, illetve közösségben felmerülő igény már lehet egy a fennmaradást meghatározó külső tényezők változására adott, adaptív válasz); illetve a felmerülő igények kielégítése is újabb és újabb, időszakos egyensúlyi állapotokat hoz létre, melyek szükségszerűen eltérnek a korábbiaktól. ${ }^{22}$ Ám a kép még így sem teljes: a változás másik kulcsát, egyben a rendszer másik nyitott pontját a választás folyamatában kell keresni. A tárgy létrehozásakor a készítő választhat a kultúra meglévő eszközkészletéből annak szabályai szerint: ez tulajdonképpen a Bourdieu-i értelemben vett struktúra, a szerzett értékek és képzetek (doxa) alkalmazása az egyéni habitusnak megfelelően. ${ }^{23}$ De a készítő hozhat ezektől eltérő, a meglévő készlettől idegen elemeket tartalmazó döntést is (agency) ${ }^{24}$ melynek lenyomata, amennyiben a választás sikeresnek bizonyul, a tárgyon megjelenve a ciklus végén beépül a kultúrába, így annak eszközkészletébe, ily módon megváltoztatva azokat.

Visszafelé, a tárgy irányából nézve a tehát minden benne kódolt információ egy adott választást reprezentál, a tárgy maga pedig különféle ismeretek és koncepciók „csomagjaként” írható le. 
E csomag egyik része az aktuálisan megjelenő technológiai elemek összessége. Másik része a vizuális koncepció, mely tartalmazza az ideális formát és díszítést (ami természetesen lehet a díszítés hiánya is). Alapvetően, de nem kizárólag díszített edények esetében pedig ezek mellett feltételezhető egyfajta mnemonikus elem jelenléte is, ami arra utal, hogy az edényhez közvetlenül kapcsolódó „csomagnak” kognitív alkotórészei is vannak.

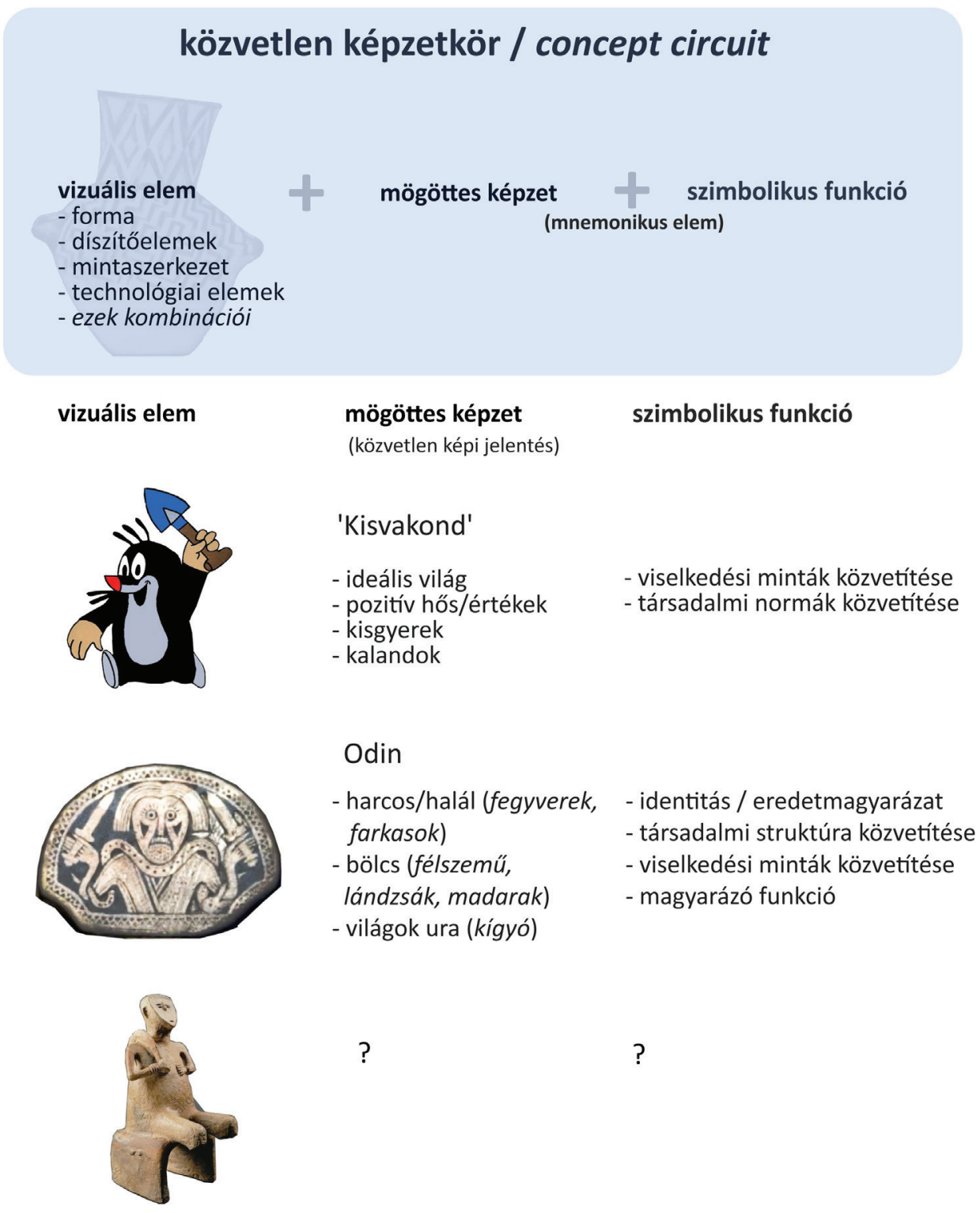

2. kép. A közvetlen képzetkör szerkezete, példákkal. Saját kultúrkörből származó ábrázolás: Kisvakond; ábrázolás írott forrásos környezetből: Odin ábrázolása az avar kori Kölked-Feketekapu B temető 85. sírjából előkerült övcsaton (VÁGó 2015, VIII. 56 nyomán); ábrázolás prehistorikus környezetből: a szegvári ’sarlós isten' (MAKKAY 1978, 2. kép nyomán).

A mnemonikus elem jelenlétére a tárgy szintjén legjobban a befektetett munka minőségi eloszlása utalhat (kizárólag azon esetekben, ahol az alkotórészek, melyekhez kognitív tartalom kapcsolódhat, felismerhetoek). Formaterv szempontjából minden tárgy „alapvet”” és „extra” elemek összességére bontható, melyek egyaránt a megjelenő stílus részei. Az alapvető elem a szükségszerü, elhagyhatatlan választásokat és munkabefektetést jelenti. Ilyen a forma, ami legtöbbször elsősorban az igény funkcionális elemeinek felel meg - jó ellenpélda a szkeuo- 
morf tárgyak csoportja, amelynél gyakran maga a forma is alapvetően szimbolikus jellegü (pl. aszkoszok vagy anthropomorf edények, fémedény-utánzatok, ökörbőr alakú bronzöntvények). A díszítés (beleértve a technikát és a mintát is) minden esetben extra elem, azaz eltérő mennyiségű extrán befektetett munkát reprezentál; aránya - egyfajta megszaladási jelenségként - esetenként pazarlóan magas lehet (pl. a fiatal neolitikumból ismert szalmaintarziás edények esetében). Ez a - D. Wengrow ${ }^{25}$ nyomán itt esztétikai munkának (aesthetic labour) nevezett - munkamennyiség ráadásul minden esetben szükségszerűen minőségi, hiszen feltételezi a szükséges technológiai és kognitív ismeretek birtoklását, valamint a releváns alkalmazási szabályok, preferenciák megfelelő ismeretét. A háttérben húzódó kognitív elem - nevezzük mögöttes képzetnek (background concept) - jelenlétére az esztétikai munka megjelenése és aránya mellett a vizuális elemek megjelenését behatároló szabályosságok jelenlétéből is következtethetünk. Ezek a szabályosságok csak több tárgy összehasonlításával válnak felderíthetővé, illetve leírhatóvá: a leírható szabályosságok szerint, tartósan visszatérő extra dizájnelemek bizonyosan rendelkeznek egyfajta mnemonikus funkcióval, melynek révén egy mögöttes képzethez vagy képzethalmazhoz kapcsolódnak. Ilyen kapcsolat fennállhat bármely konceptuális elem, például a díszítés elemei (motívumok, mintaszerkezet) és/vagy a teljes tárgy szintjén is (minta, stílus); egyszerre, azaz egy tárgyon belül akár több is. A vizuális elem és a hozzá tartozó mögöttes képzet együttesen alkotják a tárgyhoz közvetlenül kapcsolódó képzetek „csomagját” (2. kép), melyet itt közvetlen képzetkörnek neveztem (az angol concept circuit kifejezés talán még pontosabb, hiszen érzékelteti az egyes részek dinamikus viszonyát és egymásra utaltságát, valamint a rendszer zártságát is). $M$. Donald ${ }^{26}$ terminológiájával élve a (mnemonikus funkcióval rendelkező) tárgy tehát összességében a kultúra külső szimbolikus tárját képező reprezentációs rendszer egyik eleme.

A kulcs tehát, amely ezt a tárolást lehetővé teszi, az anyagi és a kognitív síkokat összekapcsoló mögöttes képzet. Ez nem más, mint a mnemonikus funkciót hordozó vizuális elem (legtöbbször minta- vagy formaelem, illetve ezek kombinációi) elsődleges, funkciótól független jelentése. Erősen leegyszerűsítve - hiszen itt a résztvevő elemek kizárólag egy-az-egyhez típusú kapcsolódása nem szükségszerű - a vizuális elem a jelalak, a mögöttes képzet pedig a közvetlen jelentés. A közvetlen képzetkörök esetében az elsődleges jelentéshez kapcsolódó vizuális elem megjelenését esetenként igen pontos, részletes, szigorú ikonográfiai szabályrendszer rögzíti (pl. a Kisvakond, Buddha különféle aspektusainak megjelenítése, vagy akár a Mikulás XX. század végére elfogadottá vált ábrázolása esetében), így az egyes megjelenések igen hasonlóak lesznek. Máskor a vizuális kánon csupán néhány ponton rögzíti a megjelenés tulajdonképpeni lényegét (azaz a jelentést), nagyobb teret hagyva az egyéni megoldásoknak (lásd pl. a középkori szentek változatos ábrázolásait). A mögöttes képzet a kultúrán belül saját, önálló funkcióval rendelkezik, mely behatárolja a tárgy szimbolikus funkcióinak körét is. Közvetíthet pl. a csoportidentitáshoz (megerősítő, ill. totemikus funkció) vagy a társadalmi struktúrához kapcsolódó eszméket, kapcsolódhat a szakrális szféra absztrakt ideológiai készletéhez, vagy megjelenítheti a közösség által elfogadott normákat, illetve tiltásokat (tabuk) is.

\subsection{A tárgyban kódolt információcsoportok elérhetösége}

Mint látható, a mögöttes képzet jelentése és funkciói is kulturálisan kötöttek, ebből következőleg bárki számára, aki nem része az adott kultúrának, nem megismerhetőek. A mögöt- 
tes képzethez egyszerre több szimbolikus funkció is tartozhat; e „funkciókészlet” összetétele, aránya és elemeinek pillanatnyi jelentősége/felhasználása a beágyazó közösség/kultúra különféle felmerülő igényeinek tükrében változhat. E látens funkciók révén a tárgy egyszerre kapcsolódhat a kultúra több szférájához, alrendszeréhez is. Tovább árnyalja a képet, hogy természetesen a mögöttes képzet maga is csak építőko, azaz egy tárgy egészéhez, illetve különféle vizuális és technológiai elemeihez (vagy ezek kombinációihoz) egyszerre több mögöttes képzet is kapcsolódhat.

A tárgyban rejlő információk elemeinek és dinamikájának ismerete mellett azt is fontos végiggondolni, melyik elem milyen mértékben érhető el számunkra, akik az egészet egy minden elemében idegen kulturális környezetből vizsgáljuk (3. kép).

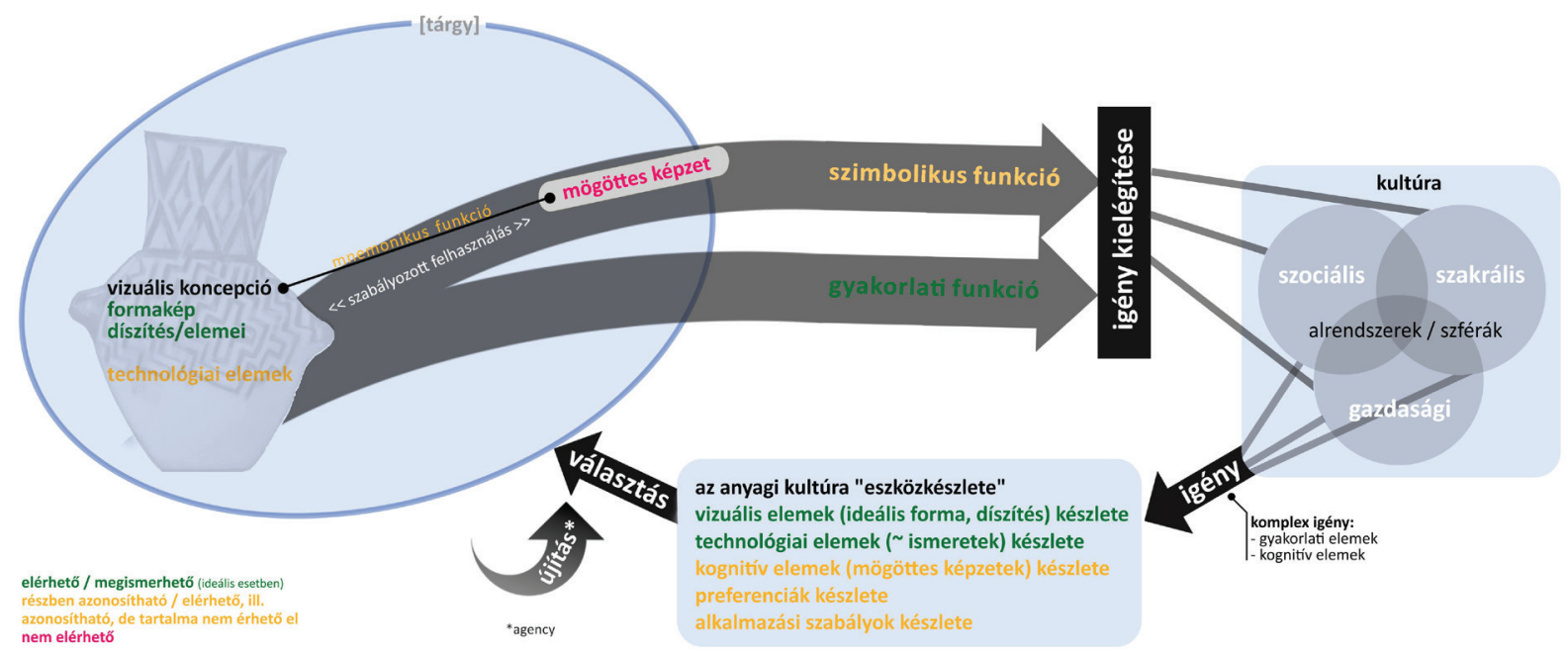

3. kép. A tárgyhoz kapcsolódó információk elérhetősége.

Megismerhetőség szempontjából a negatív végpontot a mögöttes képzet tartalma és funkciója jelentik. Minthogy a tárgyhoz kapcsolódó közvetlen képzetkört alkotó konceptuális elemek az anyagi kultúrát meghatározó kognitív elemek készletéből származnak, tartalmuk számunkra, akik nem vagyunk részei a létrehozó kultúrának, nem érhető el; azaz a vizuális (esetleg technológiai) elemek elsődleges jelentése, illetve szerepe nem érthető meg. Kissé sarkítva a másik végletet az egyszerűen leolvasható technológiai és vizuális elemek, valamint az ezek használatát behatároló szabályrendszer egy része képviselik. Elérhetőség szempontjából a köztes állapot egyetlen tárgy szintjén alapvetően nem értelmezhető; ehhez több megjelenés visszatérő szabályszerűségeit kell megvizsgálni. Közepes elérhetőségűek a rendszer azon elemei (funkciók, kapcsolatok), melyek megléte bizonyítható, de tartalma, ha van is, nem ismerhető meg. Ide sorolhatóak: az anyagi kultúra elemeinek használatát behatároló szabályszerűségek egy része; a tárgyhoz kapcsolódó közvetlen képzetkör/ök kognitív elemei, azaz a mnemonikus funkció, a tárgy által betöltött szimbolikus funkciók egy része, illetve ennek megfelelően a tárgy vagy alkotórészei és a kultúra egyes alrendszerei, szférái között megvalósuló kapcsolatok.

A mnemonikus elem és a szimbolikus funkció jelenlétére, azaz arra, hogy a tárgy mint komplex vizuális elem, vagy a rajta megjelenő valamely önálló vizuális elem nem önállóan, hanem közvetlen képzetkör részeként van jelen, a típus szintjén, több megjelenés tulajdonságainak összevetésével következtethetünk. 
Amennyiben egy adott vizuális elem nagyobb területen vagy hosszabb időn keresztül többé-kevésbé változatlan formában jelenik meg, feltételezhető, hogy esetében nem kizárólag esztétikai tényezők működnek. A fenti állítás természetesen csupán az adott elem összetettségének figyelembevétele mellett értelmezhető: minél komplexebb az adott vizuális rendszer mind a befoglalt elemek, mind pedig azok rögzített viszonyai tekintetében, annál sérülékenyebb is. A vizuális elemek önmagukban nem állnak ellen az alaki változásoknak vagy a másolási hanyatlásnak, hanem a zárt közvetlen képzetkör tartja vissza őket (ennek konceptuális elemei működés szempontjából az ideális megjelenés (formakép, ideal image), a mögöttes képzet és a felhasználási szabályok). Ez a kör több ponton is sérülhet: ha a mögöttes képzet elhalványul, megváltozik vagy elveszti a funkcióját, a mnemonikus kapcsolat áthelyeződik vagy megszűnik; a vizuális elem „egyedül marad”, és így jobban kitetté válik a különféle változásoknak és külső hatásoknak. Minél összetettebb a vizuális elem és minél szigorúbb a képzetkör belső szabályozása, annál szembetűnőbb lesz a változás. A közvetlen képzetkörök sérülését jelezheti a vizuális elemek nagyfokú torzulása vagy másolási hanyatlása; teljes tárgyak esetében a díszítésszerkezet vagy akár a díszítés egységének (tartalom+szerkezet+technológia) felbomlása, illetve több eltérő közvetlen képzetkör leolvasható elemeinek keveredése egy tárgyon belül (nem említve a használat változásait, melyek a leletkontextus eltérésében mutatkozhatnak meg). Az ilyen jellegű változások száma megsokszorozódik kulturális stresszhelyzetekben, azaz például kultúrák találkozási (interferencia) területein, ahol akár több teljesen eltérő gyökerű, hasonló funkciójú és felépítésű szimbolikus rendszer egyszerre lehet müködésben. ${ }^{27}$ Ezen esetekben, amennyiben a közvetlen képzetkör sértetlen és eredeti funkciójának megfelelően müködik, kevésbé valószínű, hogy a kulturális környezet idegen elemei hatékonyan befolyásolják a tárgy létrejöttének körülményeit (azaz, hogy a tárgy megalkotásakor a készítő a saját kulturális készletétől eltérő, az idegen tradíció jelenléte következtében rendelkezésre álló, ám számára a szükségszerű kulturális adaptáció miatt bizonytalan sikerü elemet választ). Fontos megjegyezni, hogy ez a probléma csak akkor áll fenn, ha a közvetlen képzetkör újraalkotása, azaz a tárgy készítése kevert kulturális környezetben történik; a tényleges importok nem értékelhetőek ilyen módon, mivel azok saját kulturális környezetükben készülnek, és csak utóbb kerülnek ki belőle.

\subsection{A produkciós háttér szerepe}

A tárgy azonban önmagában nem képes betölteni azt a szerepet, melyre létrejött; ez, vagyis a tárgyat eredetileg létrehívó kulturális igény kielégítése a használat során, a tárgy és a felhasználó/k közötti kapcsolaton keresztül valósul meg. Ezért a produkciós háttér, vagyis az, hogy a felhasználó a ciklus mely részén és milyen módon kapcsolódik be a tárgy „életébe”, meghatározó jelentőségü.

Az előállítás lehet nem specializált, részlegesen specializált vagy specializált (4. kép). Nem specializált gyártásnál a későbbi használó gyakran megegyezik a készítővel (illetve a használók köre nagyjából azonos a készítők körével), és a tárgy mindenképpen a felmerült igényre adott egyedi válasznak, a befoglalt képzetkör/ök egyedi rekreációjának tekinthető. Ez jelenti egyben az igényre adott legpontosabb, „személyre szabott” választ is, hiszen a későbbi használó/k már a kialakításnál, azaz az anyagi kultúra eszközkészletéből való választás lépésénél

27 Különösen abban az esetben, ha az érintkező kultúrák hasonló médiumokat használnak hasonló minőségek kifejezésére, ill. hasonló szimbolikus funkciók betöltésére. 

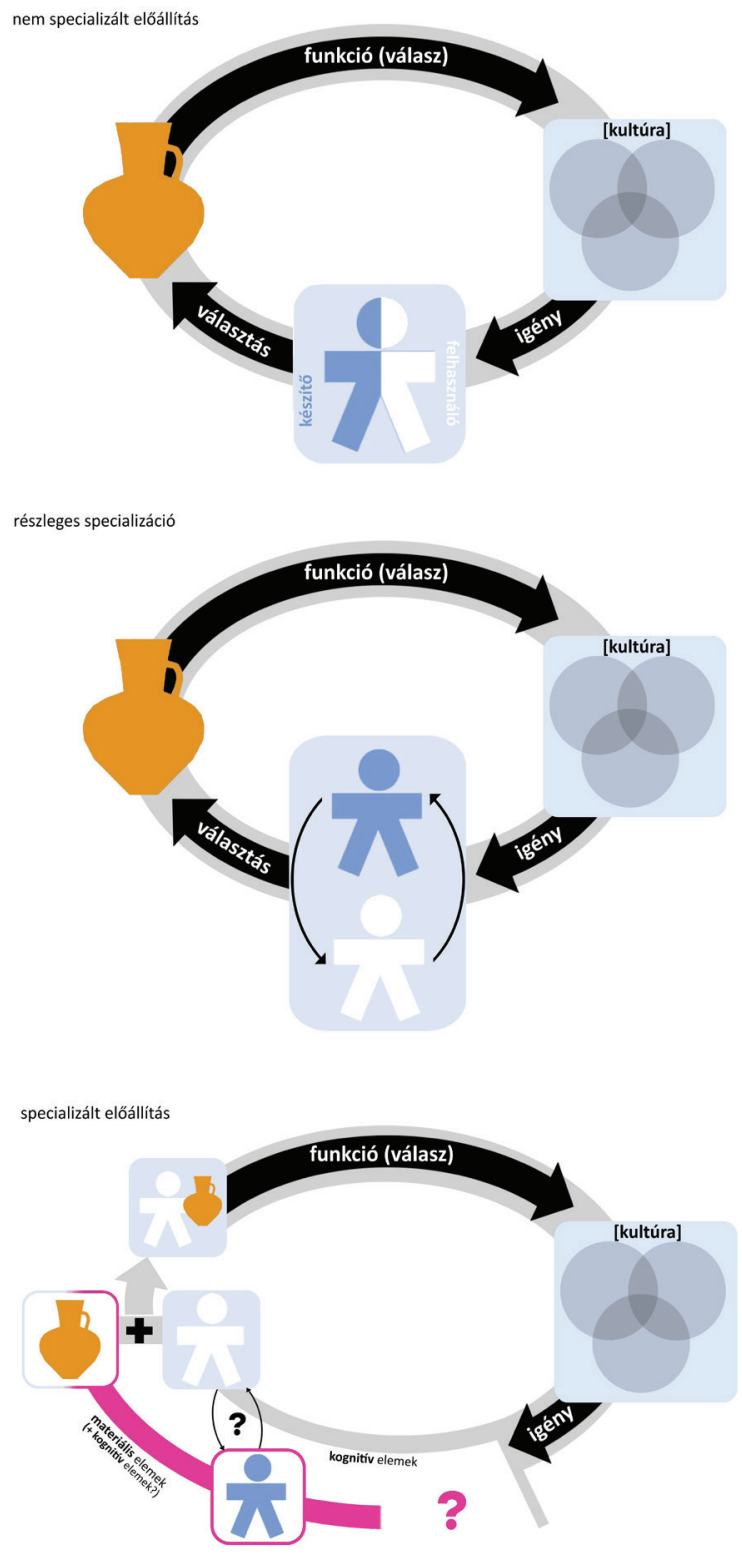

4. kép. A produkciós háttér szerepe.

kapcsolatba kerülhetnek a tárggyal; korlátozó tényezőként ez esetben csupán a (többnyire nem professzionális) készítő/k képességei és tudásbeli korlátai merülnek fel. Egy nem specializált gyártással készülő díszített edény esetében tehát a vizuális elemek maradéktalanul kiszolgálják a kognitív részt.

Egy nem specializált gyártással készülő tárgytípus megjelenései jellemzően olyan sorozatokban azonosíthatók, ahol az egyes elemek, bár legtöbbjük vagy mindegyikük követ egy közös mintát, teljesen sohasem ugyanolyanok. Azon esetekben, ahol az adott tárgy készítése bizonyos (időszakos vagy állandó) társadalmi pozícióhoz kötött, a készítőnek érdekében is állhat az individuális jegyek megőrzése, illetve az eltérésre törekvés, mely révén képességeit és tudását reprezentálhatja, vagy egyértelműen azonosíthatja magát az adott produktummal. Épp ezért - mivel a tárgy készítése önmagában presztizsértékű lehet - az extra (esztétikai) munka mennyisége és aránya a nem specializált gyártásban létrejövő tárgyak esetében a legnagyobb, azaz pl. a leginkább részletes és változatos kerámiaedény-díszítések is jellemzően e típusok között jelennek meg. ${ }^{28}$

Ha a gyártás legalább részlegesen specializált, a megjelenő sorozatok karaktere lényegi változáson megy keresztül. Ennek oka az, hogy a részleges specializáció már a folyamat teljesen más bázisra helyeződését jelenti: a készítő itt legtöbbször (direkt vagy közvetett módon) elsősorban gazdasági okokból folytatja tevékenységét. A gazdasági alapú gyártásnál alapvetően más szempontok érvényesülnek, mint a nem specializált gyártás esetében, ezért a bizonyos szintű uniformizálódás mellett számolni lehet az extra (esztétikai) munka arányának jelentős csökkenésével, ${ }^{29}$ melyet gyakran a díszítések egyszerüsödése kísér (amennyire azt az adott vizuális kánon engedi). Ez a típus szintjén a gyakorlatilag azonos elemekből álló, többé-kevésbé rövid sorozatok megjelenését, valamint a változatosság érzé-

28 Legalábbis a vizsgált terület neolitikumában. A bronzkor végétől megjelenő, magas szintű, professzionális termeléssel előállított reprezentatív (luxus-) cikkek minőségét ezek a tárgyak természetesen nem közelíthetik meg.

29 Hacsak nem kimondottan csúcsminőségű, egyedi termék elóállítása a cél; de erre - a neolitikum technológiai fejlettsége és gazdasági berendezkedése mellett, mely mind a megfelelően széles, az egyedi luxust igénylő elitet felmutatni képes társadalmakat, mind pedig a luxustermelést fenntartani képes vásárlóerőt nélkülözni látszik - a korszakban nemigen találunk példát. 
kelhető csökkenését eredményezi. A tárgy és a kultúra között fennálló dinamikus viszonyban a részleges specializáció legtöbbször azt jelenti, hogy a készítő és a felhasználó(k köre) nem azonos, de mindannyian ugyanazon kultúrához tartoznak, ezáltal a tárgyban megjelenő képzetek és koncepciók közös készletén osztoznak. A felhasználó és a tárgy azonban legtöbbször csupán a tárgy elkészültét követően találkoznak, azaz a részlegesen specializált gyártás esetében a későbbi felhasználónak alapvetően nincs ráhatása a tárgyban kódolt választások készletének összeállítására (vagy, ha esetleg mégis, csupán közvetett és/vagy korlátozott). Ez azt is eredményezi, hogy a szimbolikus funkció betöltéséhez utólagos finomhangolásra van szükség, azaz a képzetkör konceptuális elemeinek készletét (vagy akár magukat az elemeket), vagy akár a felhasználás módját is a már meglévő vizuális elemekhez kell igazítani.

A részleges specializációhoz képest a specializált gyártás nem jelent igazán nagy különbséget. Ebben a szintén nyilvánvalóan gazdasági alapú konstrukcióban gyakran jellemző a munkabefektetés minimalizálására való törekvés ${ }^{30}$ a nagyfokú uniformizálódás és egyszerüsödés (amennyire az adott vizuális kánon engedi). Ez a típus szintjén a gyakorlatilag azonos elemekből álló, hosszú sorozatok megjelenését is jelenti. Fontos különbség továbbá, hogy a specializált gyártás esetében az sem szükségszerű, hogy a készítő és a későbbi felhasználó azonos kulturális bázison osztozzanak, azaz a tárgy létrejöhet akár a kultúrán kívül is (bár ez a neolitikus kerámia esetében épp nem jellemzo). A felhasználónak ez esetben biztosan nincs lehetősége befolyásolni a tárgy végső kialakítását, így a szimbolikus funkció betöltéséhez a kognitív elemek utólagos hozzáigazítása elengedhetetlen.

A lehetőségek felsorolásánál érdemes még szót ejteni arról a jelenségről is, amikor egy készen a kultúrába érkező, idegen típus kezdetben nem rendelkezik szimbolikus funkcióval, hanem az csak utólag, az anyagi kultúra eszközkészletében meglévő kognitív elemek módosulásával jön létre. Erre H. P. Hahn ${ }^{31}$ hoz példaként egy a 17-19. században Nyugat-Afrikába exportált német edénytípust. A gazdagon díszített, finom anyagú westerwaldi korsó típusa néhány generáció alatt beépült a helyi kerámiakészletbe; az alapvető jegyek megtartásával kialakult a kultúrán belüli, önálló utánzat-típus is, melyet jelenleg (feltehetően egy meglévő szokás adaptációjaként) az „ősök edénye”-ként használtak.

Fentiekből is kitűnhet, hogy az előző pontban vázolt modell a gyakorlatban nem használható minden esetben. A szimbolikus funkció és a mnemonikus elem megléte régészeti módszerekkel biztosan csak akkor azonosítható, illetve változásaik is csak akkor követhetőek, ha azok a kognitív sík mellett megjelennek a vizuális elemek szintjén is (azaz csak a nem, illetve részlegesen specializált gyártás esetében). Ezért a vizsgálható körből (gyártástól függetlenül) kiesnek azok az esetek is, amikor a szimbolikus funkció utólag, a tárgy „élete” során, a vizuális elemek megváltoztatása nélkül társult (pl. egy sírmellékletként deponált hétköznapi edény esetében). A tárgyhoz kapcsolódó szimbolikus funkció jelenlétére további támpontot adhat még a kontextus is, ám ez a régészetben bizonytalan marker: a leletkontextus egyrészt csupán a tárgy legutolsó funkciójáról nyújthat információt, másrészt pedig általában (az aránylag ritka szándékos depozíciókat kivéve) nem aktív, használati állapotot tükröz.

A produkciós hátteret végiggondolva kirajzolódnak az egyes típusokhoz tartozó elterjedési és fennmaradási stratégiák különbségei is. A nem specializált gyártás esetében minden önál- 
ló megjelenésnél a befoglalt képzetkör(ök) eseti újraalkotása történik, vagyis a kognitív elem már a készítés folyamata során, a használatot megelőző fázisban is aktív. Ennek megfelelően a nem specializált gyártással készülő edénytípusok esetében a közvetlen képzetkör/ök vizuális és kognitív elemei szükségszerủen együtt terjednek. Minden olyan esetben, ahol a (kezdeti) szimbolikus funkció kialakulása, azaz a képzetkör vizuális és kognitív elemei közötti pontos viszony rögzülése a tárgy készítését követően zárul le, ezen elemek a típus tér- vagy időbeli terjedése során is könnyebben elválnak egymástól. Ilyenkor elsősorban a vizuális elemek terjedése figyelhető meg, míg kognitív síkon a látszólag azonos megjelenések esetében is számolni kell az egyes közösségek esetlegesen eltérő igényeihez, szokásaihoz és kognitív készleteihez való adaptációval (azaz a mögöttes tartalomnak az adott típus minden példányára kiterjedő egységessége megkérdőjelezhetővé válik). Ez esetben tehát a típus elterjedése nem szükségszerűen esik egybe a hozzá kapcsolódó mögöttes képzetek, illetve szimbolikus funkció elterjedésével: a vizuális elemek önállóan is megjelenhetnek.

A tényleges helyzet persze ez esetben sem ilyen egyszerű; a régészeti anyag számos variációval szolgál. Pusztataskony-Ledence 1. tiszai korú temetkezései esetében például elsősorban egy kognitív elem (korai lengyeli típusú funerális edénykészletek használata) átvétele figyelhető meg, míg épp a szokáshoz kapcsolódó materiális/vizuális rész változik az adaptáció folyamatában (helyi edénytípusok használata az eredeti lengyeli formák helyett). ${ }^{32}$

\section{A felhasználás módjai: az edény mint szignál}

Annak megértéséhez, hogy az elkészült tárgy milyen módon felel meg az őt létrehívó komplex igény elemeinek, a hozzá kapcsolódó gyakorlati és szimbolikus funkciók jellegét és jelentőségét érdemes végiggondolni. Nonverbális kommunikáció médiumaiként tekintve rájuk elmondható, hogy minden tárgy (és az épített környezet minden eleme is) rendelkezik egy gyakorlati és egy szignálfunkcióval.

A szociális szignalizáció az egyének és csoportok közötti interakció legfontosabb eszköze; gyakorlatilag az egyén és a befoglaló csoport társadalmi képeinek (social image) független kivetítése, állandó reprezentációja (5. kép). A szignálok révén az egyén vagy csoport képes folyamatosan ,jelen lenni” a fizikai, szociális vagy kognitív tér bármely szegmensében. Ennek jelentősége különösen a letelepedett életmóddal párhuzamosan intenzifikálódó, illetve rögzített területhasználattal növekszik meg. ${ }^{33}$

SEвŐк 2012, 114. Ez természetesen többféleképp magyarázható. Lehetséges például, hogy a funerális készletet alkotó edénytípusok a lengyeli kultúrán belül önálló jelentéssel bírnak, melyet mintegy „le kellett fordítani” a befogadó közösség szimbolikus nyelvére, azaz megtalálni azokat a helyi típusokat, melyek valamely szempontból hasonló tartalommal rendelkeznek. Ugyanakkor az is elképzelhető, hogy az egyedi típusok - legalábbis funerális kontextusban - önmagukban nem bírnak jelentéssel, azaz nem birtokolják a funerális készlet jelentésének egy-egy darabkáját; a temetkezés szempontjából pedig minden egyéb, nem-gyakorlati jelentésük lényegtelen. Jelen esetben a terjedésnél a szokás (a halott bizonyos módon való ellátása, reprezentációja) átvétele tűnik elsődlegesnek, mely magával hozza a kifejeződés (funerális edénykészlet) megfelelő formáját, míg az eszközkészlet (megfelelő edénytípusok) vizuális eleme, pontosabban stílusa kevésbé lényeges. Azaz a szimbolikus funkció szempontjából a tárgy önmagában másodlagos, mivel azt elsősorban a készlet (összeállítása) és a leletkontextus közvetítik. Ennek megfelelően a bekerült tárgyak - legalábbis Pusztataskony esetében - másodlagos felhasználásúak, és egy kivételt leszámítva nem kerültek módosításra a sírba helyezés előtt (ld. lentebb); azaz a produkciós háttér ez esetben lényegtelen, mivel a tárgy megformálásakor az utolsó funkció még nem volt aktív.

33 DeMarrais et al. 2004, 4-5 további irodalommal; Szeverényi 2011, 215. 


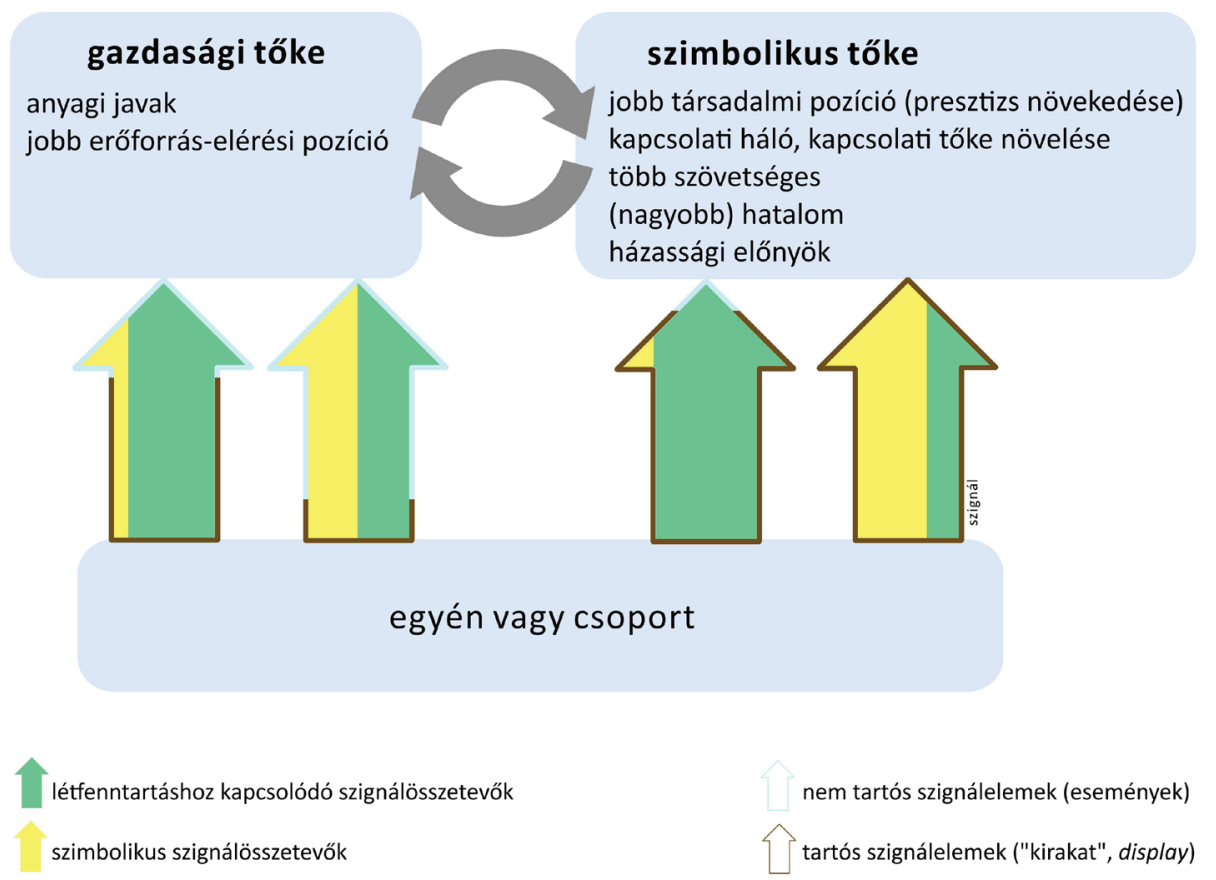

5. kép. A szociális szignalizáció működése: a közlő (egyén vagy csoport) a változó összetételű, pillanatnyi és állandó (elemeket is tartalmazó) szignálok révén saját gazdasági, illetve szimbolikus tőkéjét növeli, melyek egymásba konvertálhatók (BLIEGE BIRD - SMITH 2005 nyomán). E szignálok révén a közlő folyamatosan újrapozicionálja magát a társadalmon belül.

A szociális szignalizációban szerepet kap a fizikai világ minden eleme: a térhasználat és az épített térelemek; az épületek; a használati és viseleti tárgyak; valamint a különféle rítusok. ${ }^{34}$ Ebben a viszonylatban a módosított környezet elemei - változó mértékben - szignálként, tehát a szociális szignalizáció moduljaiként, azaz a kultúra külső szimbolikus tárolórendszerének elemeiként jelennek meg. A szignál az állandóan változásban lévő „társadalmi valóság” folyamatos újrateremtésének egyik eszköze. ${ }^{35}$

Az adott tárgy szignálfunkciójának jellegére a benne kódolt szignálösszetevők számba vételével következtethetünk. Ezek az összetevők egyaránt lehetnek megújulóak és nem megújulóak (6. kép); típusuk szerint alapvetően három csoportba tagolhatók. ${ }^{36} \mathrm{Az}$ első csoport a szignál tartalmi elemeit jelenti, melynek részei a kognitív struktúra vonatkozó ideái, a felhasznált ismeretek, a felhasználási szabályok és preferenciák (együttesen a kognitív vagy kulturális hagyomány elemei). A második csoportot a befektetett munka és a megjelenő készségek adják. A harmadik csoportba a beépített („feláldozott”, azaz a gazdaságból kivont) erőforrások sorolhatók. Ezek értéke lehet elsősorban piaci (pl. spondylus, réz, kőnyersanyagok) vagy inkább szimbolikus eredetű (pl. okker); de ide sorolható a befektetett munka, sőt az életerő is (meghatározó összetevő pl. a parázson járás vagy az eredeti bungee jumping rítusainál).

Az egyes szignálok esetében a szignálösszetevők aránya, valamint az elemek életciklusa és mobilitása egyaránt befolyásolja a müködés mechanizmusát, illetve azt, hogy a szignál a kommunikáció mely szegmensében juthat szerephez. Ennek megfelelően az egyes típusok

36 Bliege Bird - SMith 2005, 228-232. 
a csoportszerveződés eltérő szintjeihez kötődhetnek; ez egyaránt jelenti a szignált létrehozó (közlő) csoportot és a befogadó oldalt is (mind közlés, mind befogadás szempontjából teljesen más pl. egy körárok és egy díszített edény szignálfunkciója).

Ha a szignál nagy arányban tartalmaz munkát és nem megújuló erőforrásokat, hatásmechanizmusának lényegi eleme a közlő egyén vagy csoport gazdasági erejének megmutatása (költséges szignalizáció, costly signaling). Egyúttal - épp a szignálösszetevők jellege miatt - ez az a szignáltípus, mely legvalószínúbben régészeti módszerekkel vizsgálható nyomot hagy. A vizsgált korszaknál maradva: költséges szignálként foghatók fel például a szimbolikus jelentőségü újkőkori körárok-rendszerek; a gazdag temetkezések, melyekben az elhunyt vagy a mögöttes csoport (pl. gazdag gyereksírok esetében) gazdasági ereje és pozíciója tükröződik; a lakomák; de akár a díszített edények is. A szignáltípusok közül a költséges szignalizáció jelenti a legbiztonságosabb lehetőséget, mivel a szignál értékét adó elemek ez esetben nem vagy igen nehezen hamisíthatóak (tehát igen alacsony annak valószínűsége, hogy a szignál hamis, ami a kommunikáció hitelességét ásná alá). A jelen tanulmány kiindulási anyagát jelentő forráscsoport, vagyis az újkőkori kerámia díszített változatainak esetében a felismerhetō ${ }^{37}$ szignálösszetevők közül kiemelkedik az esztétikai munka (melynél nem csupán a befektetett munka mennyisége, de a tükröződő ismeretek és képességek is emelik a szignál értékét); emellett különösen a festett edények esetében számolhatunk még a felhasznált anyagok szimbolikus, illetve piaci értékeinek értéknövelő szerepével is.

\section{A SZIGNÁL ÖSSZETEVŐI}

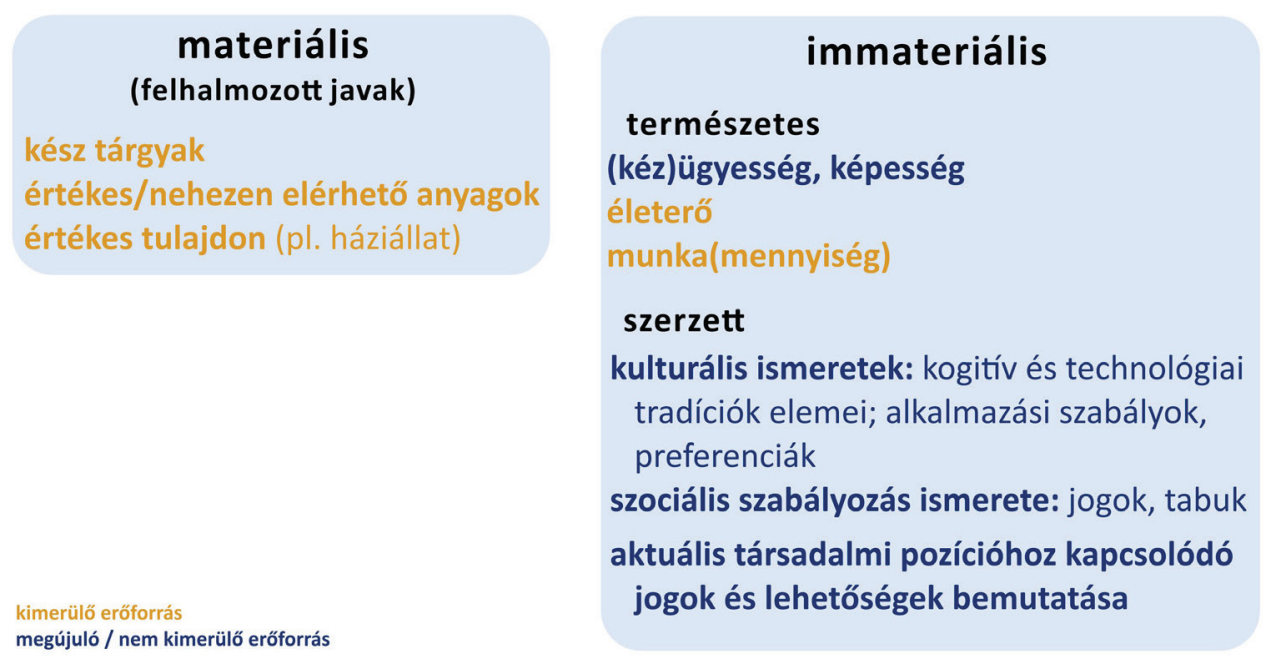

6. kép. A szignál összetevői (részben Bliege BiRd - SMITH 2005 nyomán).

Számos részlet utal arra, hogy a kerámia mint a szignál alapvetően elsősorban a mindennapok gyakorlatához kötődik (ellentétben pl. a körárkokkal vagy a temetkezésekkel). Egyrészt, a kerámiából készült (fokként használati) tárgyak a alapvetően a mindennapi élet részei. $\mathrm{Az}$ alapanyag könnyen formálható (és díszíthető), ugyanakkor tartós. Az edénykészítés aránylag kis munka- és anyagbefektetést igényel, azaz egy ember elegendő az adott tárgy

37 Hiszen lehetnek olyan beépített összetevők is, melyek értéke szimbolikus, csak a kultúrán belül releváns, és nincs olyan megjelenési formája, melynek segítségével jelenéte a régész számára is azonosítható volna. Ilyen összetevő lehet pl. egy speciális, külön jelentéssel rendelkező forrásból származó agyag vagy víz, esetleg speciális szimbolikus tartalommal bíró edényekből származó kerámiazúzalékkal való soványítás. 
előállításához (az égetést leszámítva, amely azonban szintén kisebb csoport kooperációjával megvalósítható); és a befektethető alap és extra munka mennyisége is az egyén dimenziójában mozog (ellentétben pl. egy épület munkaigényével). Az inventárban feltűnő kerámiatárgyak életciklusa és funkciója eltérő; ennek megfelelően a háztartásban megjelenő kerámiakészlet is több csoportra bomlik: ezek a foző, tároló és „tálaló” (reprezentatív) edények halmazai. ${ }^{38}$ Ezek közül az első általában kevésbé vesz részt a szociális szignalizációban, mivel élettartama rövidebb, illetve használta nem kötődik a szociális térhez. A tárolóedények élettartama adott esetben jóval hosszabb lehet, és e tárgyak esetenként állandóan szem előtt vannak, azaz a csoport (ez esetben a háztartás) által közölt tartalom hosszú távú megjelenítésére alkalmasak (pl. a nem mobilis nagyméretű vagy beépített tárolók). ${ }^{39}$ Ezért általában a kisebb, mobilabb, jó minőségű edények jelentik a szignalizáció fő terepét. Ez a szignálfunkció-beli különbség jól megmutatkozik pl. a vonaldíszes tradíció kerámiainventárjaiban. E kultúrák kerámiakészleteiben az esztétikai munka eloszlása igen egyenlőtlen, azaz a legtöbb típuson leginkább maximum kevés munkaráfordítással kialakítható, elsősorban funkcionális díszítések (fogóbütykök és borda, felületnövelő felületkezelések és rátétek) figyelhetők meg, míg a nagyobb vagy kimondottan nagy arányú extra munkabefektetés (aránylag gazdag díszítés) egy-két, általában kisebb, általában zárt formához kötődik (jelző típusok, signature types). A jelző típusok díszítése általában karcolt (vonaldíszes kultúra, tiszadobi csoport), néha festett (esztári csoport, herpályi és lengyeli kultúrák), de ezek kombinációja is előfordul (bükki és tiszai kultúrák).

A jelző típusok szignálfunkciója- a mögöttes képzet kapcsolódásainak megfelelően - igen változatos lehet. Kapcsolódhat a presztizs ${ }^{40}$ vagy a társadalmi pozíció kifejezéséhez, ${ }^{41}$ a kulturális vagy csoportidentitás eltérő formáihoz; ${ }^{42}$ valamint a rituális szféra absztrakt ideológiai készletéhez. ${ }^{43}$ A díszített kerámia a szociális szignalizáció egyik elsődleges médiuma a Kárpát-medence középső és kései neolitikumában; e szerepét fokozatosan, a közölni kívánt tartalom eltűnésével (életmódváltás), illetve a funkció újonnan megjelenő médiumokra (pl. réz $z^{44}$ ) való áttevődésével, nagyjából a korszak végére veszíti el.

\section{A tárgyak élete}

A tárgy és a beágyazó kultúra közötti kezdeti viszony pontos részletei tehát (nem specializált gyártás esetén) a tárgy készítésekor (más esetekben az első használatba vételkor) kerülnek rögzítésre. Emellett azonban a használat során minden tárgy időszakosan további szerepekhez juthat, melyek új kapcsolódásokat hozhatnak létre a kultúra szociális, szakrális és/vagy

38 A neolit lelőhelyek kerámiaanyagában gyakran megjelenő speciális formájú agyagtárgyak és miniatűr edények ezúttal szándékosan maradtak ki a felsorolásból, mivel azok esetében a gyakorlati funkció kontextusa vélhetően eltér az inventár bázisát képező típusokétól (ezért ez az azokkal közös halmazba foglalás előtt legalábbis bizonyításra szorul).

39 Esetükben a szignálérték becslésekor az esztétikai munka aránya jóval kisebb lehet a teljes munkamenynyiségen belül (azaz a nagyméretű tárolók szignálértéke magasabb lehet csupán azért, mert nagyobb idő- és munkaráfordításba kerül létrehozni őket). Emellett a tárolók esetében a kapacitás is meghatározó szignálösszetevő lehet.

40 Lichardus - Lichardus-ItTtEN 1997, 207-210.

41 Siklósi 2004, 4-6; ZALAI-GAÁl 2001, 46; ZALAI-GAÁl 2002, 74; ZALAI-GAÁL 2008, 269; ZALAI-GAÁl $2010,76$.

42 Seвő 2009, 14-16; SEвőк 2012, 114; Zeeb-LanZ 2003, 35; ZeEb-LANZ 2006, 84-95, Abb. 12.

43 Kalicz 1998, 101.

44 SikLósi 2013, 222-223. 

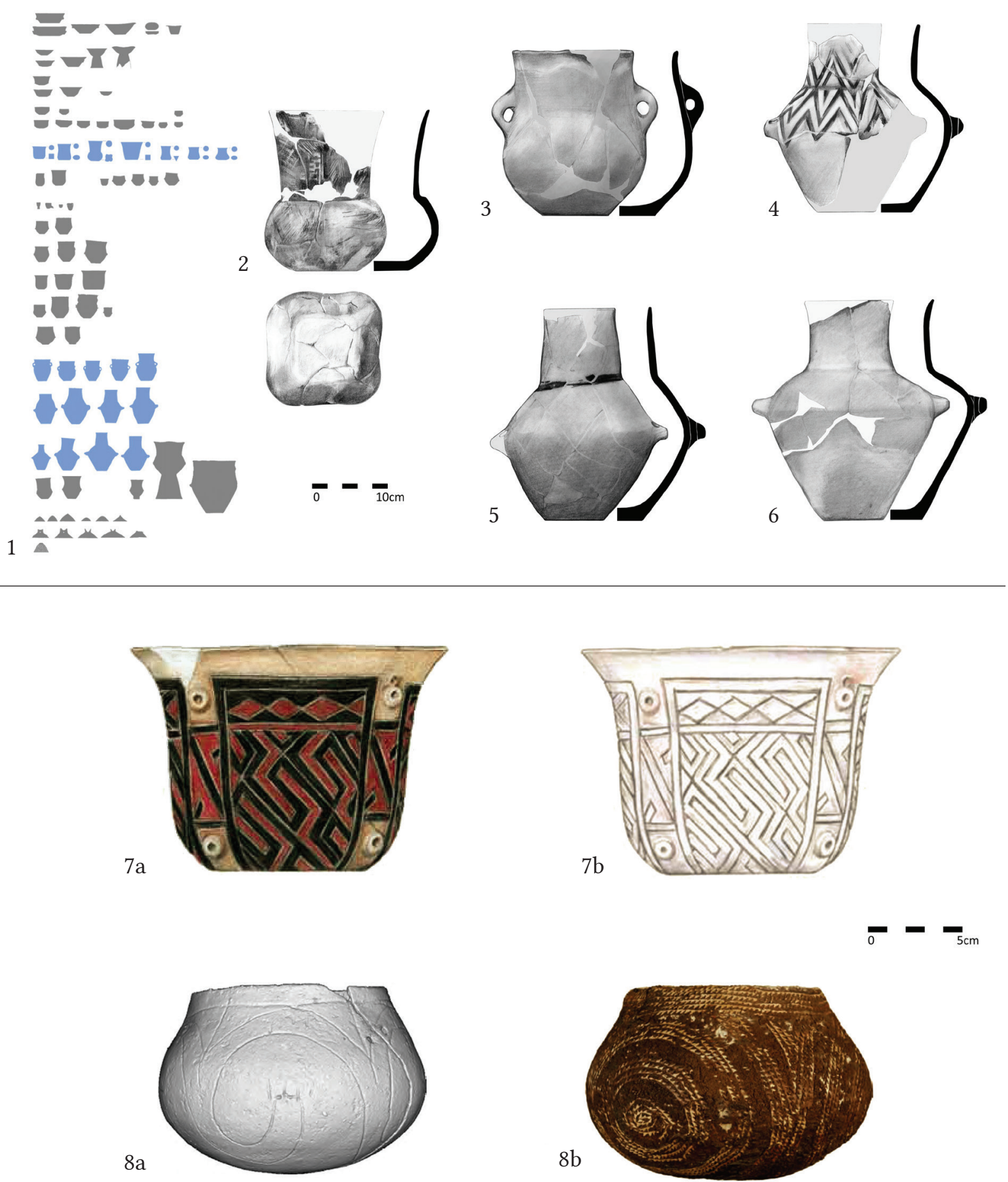

7. kép. Funkcióváltás az edény élete során, példák. 1-6 - A Polgár-Csőszhalom-dúlő 272. objektumában (kút) feltárt edénydepó esetében a funkcióváltást nem kíséri alaki változás, csupán a használati kontextus változik. 1: a lelőhely kerámiainventárja, kékkel kiemelve a kútban megjelenő típusok, 2-6 példákkal (SЕво̋к et al. 2013, 4. kép 3, 7. kép 3, 8. kép 5, 9. kép 10, 12. kép 9, 15. kép nyomán). 7-8 A funkcióváltást alaki változás és a kontextus megváltozása kíséri. 7 - Textildíszes edény Pusztataskony-Ledence 1. 65. számú, tiszai korú sírjából. Az eredetileg vörös-fekete utánfestett edényt (7a) a temetés előtt, feltehetően annak részeként fehér bevonattal látták el (7b) (RACZKY - ANDERs 2011, Fig. 3. nyomán), 8 - Szalmaintarziás, gyantabevonatos edény Skeuditz-Altscherbitz korai vonaldíszes kútjából. Az eredetileg karcolt díszes edény (8a) felületén a kútba helyezés előtt alakították ki az aprólékos második díszítést (8b) (Elburg 2013, Fig. 11a-b nyomán). 
gazdasági szféráival. Az sem szükségszerű továbbá, hogy minden, a megformáláskor beépített kognitív funkció egyszerre aktív legyen; nem zárható ki, hogy az egyes kognitív és szignálfunkciók meghatározott helyzetekhez kötődnek, így a tárgyban csupán látens módon vannak jelen. Például a Polgár-Csőszhalom-dűlő 272. számú kútjában talált edénydepó elemzése ${ }^{45}$ kimutatta, hogy a településen használt kerámiainventárból csupán néhány típus (kétfülü hasas és vállas korsók; változó keresztmetszetű, szalmaintarziás edények) rendelkezik azzal a szimbolikus vagy szignálfunkcióval, mely alkalmassá teszi őket arra, hogy az adott depót létrehozó rituálé részei legyenek (7. kép 1-6). Minthogy a depót alkotó példányok alapvetően nem különböznek az adott típusok többi, „mindennapi” kontextusban megjelenő előfordulásától, feltehető, hogy az itt megfigyelt szimbolikus funkció látens módon minden, a településen előforduló ilyen edényben benne van, de csupán az adott rítus lefolytatásakor, azon keresztül mutatkozik meg. Hasonló lehet a helyzet a vonaldíszes csoportok, illetve a lengyeli kultúra temetkezéseiben mellékletként megjelenő „hétköznapi” edények esetében is.

Igen ritkán, eseti jelleggel az újonnan fölvett szimbolikus funkciót alaki változás is jelzi (azaz a változás nem a teljes típust, csupán annak egy-egy példányát érinti). Például Pusztataskony-Ledence 1. 65. számú, tiszai korú sírjából (többek között) egy jellegzetes, virágcserép alakú edény is előkerült (7. kép 7). ${ }^{46}$ Ezt az edényt eredetileg fekete és vörös festéssel hangsúlyozott, részletgazdag, karcolt textildíszítés fedte, melyet a sírba helyezés előtt fehér festékréteggel fedtek el (7. kép 2). Minthogy ez esetben a funerális edénykészlet használata egyben idegen (a lengyeli kultúrából átvett) kognitív elem átvételét jelzi, melyben a textildíszítés által közvetített tartalom ${ }^{47}$ szükségszerűen nem lehet jelen, ez az átfedés egyaránt szólhat az új kontextusban a befogadók számára különösen zavaró, oda nem illő üzenet semlegesítéséről, valamint az edény új jelentéstartalommal való felruházásáról ${ }^{48}$ Hasonló gondolatmenet sejthető pl. két, Altscherbitz késő újkőkori kútjából származó edényke esetében is: ezeknél a Šárka típusú karcolt díszítést fedte el a később rájuk applikált gyantabevonat (7. kép 8). ${ }^{49}$

Òsszességében tehát minden edény egyszerre tarthat fenn állandó és időszakos kapcsolatokat a kognitív szférával és a társadalmi szféra akár több eltérő szintjével vagy egységével. E kapcsolatok jelentősége időben is ingadozik, azaz erősödhet vagy gyengülhet.

A használatot, illetve egész pontosan a használat során a különféle szociális, gazdasági egységekkel és más társadalmi csoportosulásokkal kialakuló viszonyt az egyéb meghatározó aktív, független tényezők (technológia, társadalmi és gazdasági szerveződés) túl nagy száma miatt észszerűbb egy esettanulmányon keresztül szemléltetni; ehhez a Polgár-Csőszhalom-dűlő horizontális telepén megismert struktúra vázlatát fogom használni. Itt a megragadható állandó szociális modulokat az egyén, a háztartás és a település egysége jelentik; emellett számolni lehet különféle (például gazdasági vagy szakrális célú), változó méretű (telepen belüli vagy akár több település népességének meghatározott részét magába foglaló), időszakos csoportosulások jelenlétével is. A településen a technológiai környezet kerámiaedények szempontjából igen egyszerű; az égetés szabályozatlan, a kerámiaanyagban pedig egyelöre nem találtunk olyan jellegzetességet, ami nagyfokú kézmúves specializációra engedne következtetni. Sőt, a díszített

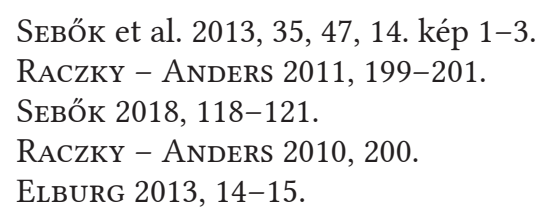


edények esetében gyakori, hogy egyazon típus különböző darabjai igen eltérő minőségűek például a díszítés kivitelezése szempontjából; ez egyrészről arra utal, hogy a készítőt legalább esetenként nem kézügyessége alapján választották ki, másrészről viszont arra is, hogy az egyes díszítések kialakításánál nem feltétlenül az esztétikai minőség volt az elsődleges szempont.

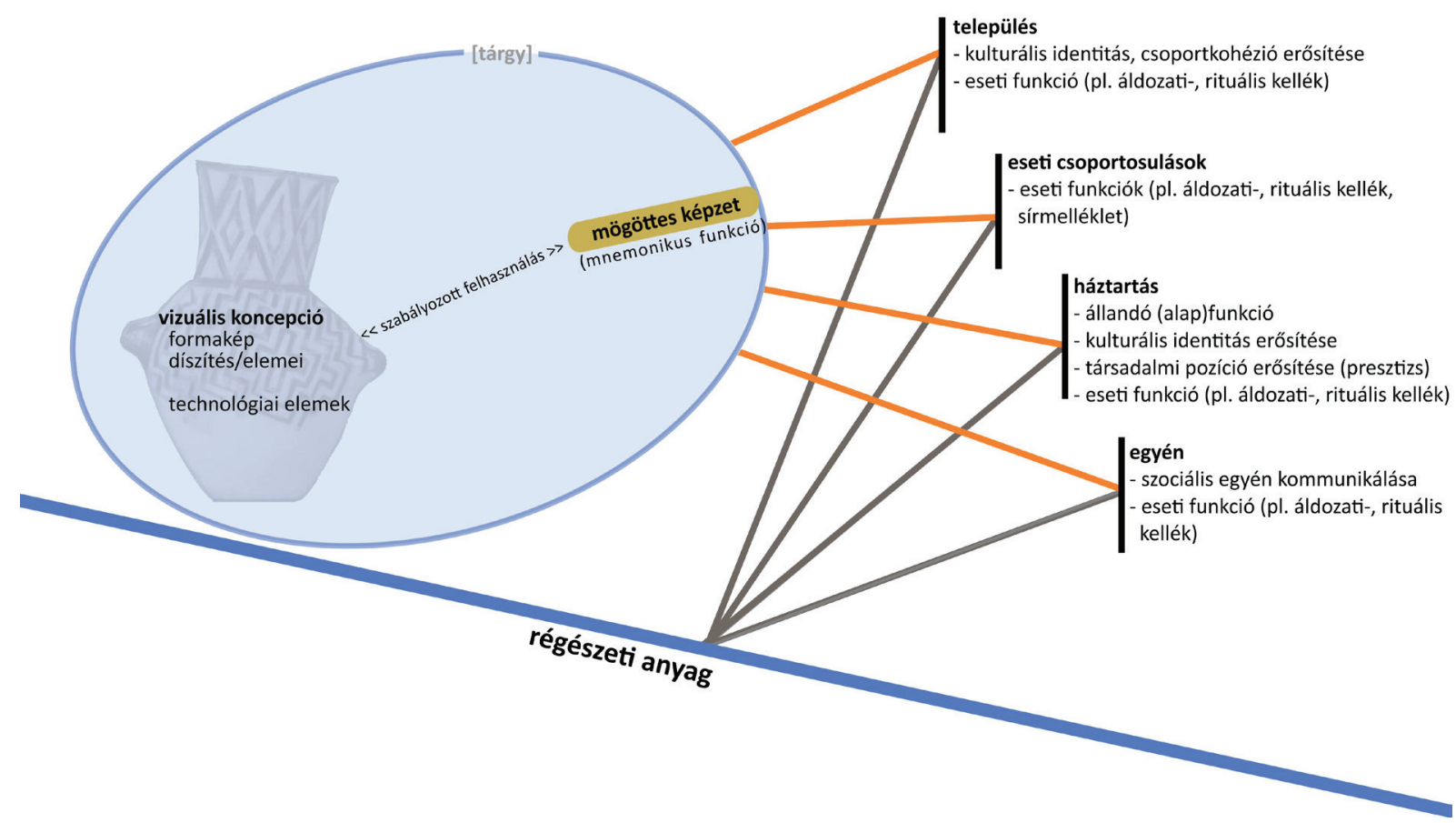

8. kép. A tárgy és a használó közösség viszonyának vázlata a Polgár-Csőszhalom kései neolitikus telepén megismert szociális modulok felhasználásával. Az eseti csoportosulás nem kizárólag telepen belüli, de több település népességének meghatározott részét magába foglaló egység is lehet (RACzKY SЕво̋K 2014, 63).

Az edény tehát egyszerre, más-más jelentéstartalommal kapcsolódhat akár minden szociális modulhoz (8. kép); az egyén szintjén például az edény készítőjéhez. Érdemes végiggondolni, mit is jelenthet ez az ő szempontjából. Az edénykészítés „joga” (főleg a szignáltípusok esetében) ebben a környezetben az egyén számára lehetőséget jelent kulturális ismereteinek és személyes képességeinek bemutatására, melynek eredményeképp egy olyan tartós, független (extraszomatikus) reprezentációt hoz létre, melyen keresztül folyamatosan erősítheti szociális képét, azaz javíthatja társadalmi megítélését; ez kihathat például a háztartás szintjére is, melynek presztizsét szintén emelheti egy jól sikerült tárgy. Ez adott esetben az adott típust akár egyfajta versengés terepévé is teheti, mint például a mai Bolívia területén a prekolumbián időszakban készített ún. chica edények esetében. ${ }^{50}$

Az összetettebb modulok esetében ilyen pontos kapcsolat nem írható le, de néhány funkció működése minden esetben valószínűsíthető: ilyenek az edényeknél alapvető gyakorlati funkció mellett a stílus kulturális identitáshoz kapcsolódó megerősítő funkciói a közösségen belül

50 Ez az edénytípus a háztartás edénykészletének részét képezte. Használata meghatározott szituációkhoz kötődött: ebben szolgálták fel a kukoricasört (chica) a vendégeknek, illetve a háztartáson belüli ünnepeken (JENNINGS - ChATFIELD 2008, 201). A chica edényt mindig az adott háztartásban élő nők készítették el; az edények gazdag díszítése a benne kódolt szignálok révén a háztartás gazdasági erejének és kulturális hovatartozásának permanens, független kifejeződéseként szolgált (BOwSER 2000, 227). A típus gyorsan a szimbolikus versengés médiumává vált, ami a kialakítás és a díszítés változatosságának robbanásszerű növekedéséhez vezetett. 
és elkülönítő funkciói a közösségek között; valamint az időszakosan felvett vagy megjelenő szerepek, melyek közül a szakrális szférához kötődőek (lakoma és más rituálék) természetüknél fogva például bármelyik modulhoz kapcsolódhatnak.

Fontos azonban szem előtt tartani, hogy a legtöbb esetben a telepanyagban előforduló edények és edénytípusok különféle „használati röppályái”, életútjai nem különíthetőek el, minthogy ezek a régészeti anyagban együttesen jelennek meg (8. kép). A (legutolsó) használat jellegét illetően is pontosabbat csak akkor lehet mondani, ha a használat megszűnését kísérő folyamatok régészeti módszerekkel vizsgálható, elkülöníthető jelenségeket eredményeznek. Ez lehet például (a típus viszonylatában) a szokásostól eltérő leletkontextus, edényösszetétel vagy fragmentációs profil, mint például a fentebb említett, a külső telepen feltárt, edénydepót tartalmazó kút esetében, amely történetesen mindhárom fenti kitételnek megfelel.

\section{Összegzés}

A kerámia mint forráscsoport valódi értékét a technológiai, kulturális és kognitív tradíciók nyomai, a társadalmi és gazdasági struktúrára vonatkozó információk, az egyének és csoportok kommunikációjára, megjelenésére, szerveződésére utaló jelek adják. Ezek - megfelelő forrásanyag esetén - kizárólag egymás, valamint a többi elérhető forráscsoport viszonylatában vizsgálva válnak értelmezhetővé. A rendszer látszólag összetett, ám az egyes szempontok választások jól kiolvasható készletét kínálják, lehetőséget nyújtva arra, hogy az értelmezés során az egyes forráscsoportok közötti viszonyban rejlő információk is hasznosuljanak.

\section{Köszönetnyilvánítás}

A jelen íráshoz kapcsolódó alapkutatások az NKFIH támogatásával jöhettek létre: Polgár-Csőszhalom kerámiaanyagának feldolgozása az NK 101024 pályázat (témavezető: Raczky Pál), míg Pusztataskony-Ledence 1. régészeti anyagának feldolgozása a PD 116711 pályázat keretében valósulhatott meg. Ezúton is köszönöm Raczky Pálnak a lehetőséget, hogy Polgár-Csőszhalom újkőkori kerámiaanyagával dolgozhatok. Hálás vagyok Kondé Zsófiának az angol nyelvü változat nyelvi lektorálásáért.

\section{References - Irodalom}

Bentley, R. A. - Maschner, H. D. G. 2008: Complexity theory. In: Bentley, R. A. - Maschner, H. D. G. Chippindale, C. (eds.): Handbook of archaeological theories. Altamira Press, Plymouth, 245-272.

Bliege Bird, R. - Smith, E. A. 2005: Signaling Theory, Strategic Interaction, and Symbolic Capital. Current Anthropology 46, 221-248.

Bourdieu, P. 1990: The logic of practice. Stanford.

Bowser, B. 2000: From pottery to politics: An ethnoarchaeological study of political factionalism, ethnicity, and domestic pottery style in the Ecuadorian Amazon. Journal of Archaeological Method and Theory 7, 219-248.

Cowgill, G. L. 2000: „Rationality” and contexts in agency theory. In: Dobres, M. A. - RobB, J. E. (eds.): Agency in archaeology. London, 51-60.

DeMarrais, E. 2004: The materialization of culture. In: DeMarrais, E. - Gosden, C. - Renfrew, C. (eds.): Rethinking Materiality. Engagement of Mind with Material World. Macdonald Institute Monographs, Cambridge, 11-22. 
Demarrais, E. - Gosden, C. - Renfrew, C. 2004: Introduction. In: DeMarrais, E. - Gosden, C. RENFrew, C. (eds.): Rethinking Materiality. Engagement of Mind with Material World. Macdonald Institute Monographs, Cambridge, 1-10.

Donald, M. 1998: Hominid enculturation and cognitive evolution. In: Renfrew, C. - Scarre, C. (eds.): Cognition and Material Culture: the Archaeology of Symbolic Storage. Macdonald Institute Monographs, Cambridge, 7-17.

Donald, M. 2001: Az emberi gondolkodás eredete. Budapest.

ElbuRG, R. 2013: Bandkeramiek anders: een vroeg-neolitische waterput uit Altscherbitz (Saksen, Duitsland). Archeologie 14, 5-27.

Hahn, H. P. 2012: Circulating Objects and the Power of Hybridization as a Localizing Strategy. In: Stocкhammer, P. W. (ed.): Conceptualizing Cultural Hybridization. Berlin-Heidelberg, 27-42.

Jennings, J. - Chatfield, M., 2008: Pots, Brewers, and Hosts: Women's Power and the Limits of Central Andean Feasting. In: Jennings, J. - Bowser, B. (eds.): Drink, Power, and Society in the Andes. Gainesville, Fl., 200-231.

Kalicz, N. 1998: Figürliche Kunst und bemalte Keramik aus dem Neolithikum Westungarns. Archaeolingua, Series Minor 10, Budapest.

Lichardus, J. - Lichardus-ItTen, M. 1997: Spätneolitische Funde von Čičarovce (Ostslowakei) und das Obere Theißgebiet an der Schwelle zur frühen Kupferzeit. Saarbrücker Studien und Materialien zur Altertumskunde 4-5 (1995-1996), 143-249.

MAKKAY J. 1978: A szegvár-tűzkövesi újkőkori férfiszobor és a „föld és ég elválasztásának” ősi mítosza. Archaeologiai Értesitő 105, 164-183.

RACzky, P. - ANDERs, A. 2011: "A colourful message": a special grave of the late neolithic Tisza culture. In: Borhy, L. (ed.): Studia celtica, classica et romana Nicolae Szabó septuagesimo dedicate. Budapest, 193-202.

RAczкy, P. - SевŐк, K. 2014: The outset of Polgár-Csőszhalom tell and the archaeological context of a special central building. In: Forţıu, S. - CînTAR, A. (eds.): Arheovest II. In honorem Gheorghe Lazarovici, Interdisciplinaritate în Arheologie, Timişoara, 6 decembrie 2014. Szeged, 51-100.

Sево̋к K. 2009: A tiszai kultúra geometrikus díszú agyagtárgyai (Clay objects with geometric decoration in the Tisza Culture). PhD dissertation, Eötvös Loránd University, Budapest. Manuscript.

Sєво̋к K. 2012: Lengyeli eredetű hatások az Alföld kései neolitikumában. Pusztataskony-Ledence 1. feltárásának első eredményei (Influences of Lengyel origin in the Late Neolithic of the Great Hungarian Plain. First results from the excavations at Pusztataskony-Ledence 1.). Archaeologiai Értesitő 137, 97-123. Full text available in English at: https://elte.academia.edu/KatalinSeb\%C5\%91k/Papers.

SEBőK, K. 2018: Evolution of a design system in the eastern part of the Carpathian Basin. Transformations of the vessel-based human representations of the Middle Neolithic Szakálhát culture and the genesis of the Late Neolithic Tisza culture's 'textile' decoration. In: SAUvET, G. - Fritz, C. (eds.): Role of Art in prehistory - UISPP 2014. Quaternary International 491 (SI), 110-124.

Sebők K. - Faragó N. - Hajdú Zs. - Anders A. - Raczky P. 2013: Egy különleges kút és leletei Polgár-Csőszhalom késő neolitikus településéről (An unusual well and its finds from the Late Neolithic settlement at Polgár-Csőszhalom). Archaeologiai Értesítô 138, 29-79.

SikLósI, Zs. 2004: Prestige goods in the Neolithic of the Carpathian Basin. Material manifestations of social differentiation. Acta Archaeologica Academiae Scientiarum Hungaricae 55, 1-62.

SikLósI, Zs. 2013: Traces of Social Inequality during the Late Neolithic in the Eastern Carpathian Basin. Dissertationes Pannonicae 4/3, Budapest.

SZEVERÉNYi V. 2011: Bronzkori „háztűznéző”: szándékos házégetés és anyagi metaforák a Kárpát-medence kora és középső bronzkorában (Deliberate house-burning and material metaphors in 
the Early and Middle Bronze Age of the Carpathian Basin). Ösrégészeti Levelek - Prehistoric Newsletters 13, 215-232.

Toren, C. 1999: Mind, Materiality, and History. London.

VÁGó Á. 2015: A Kárpát-medence ősi kincsei a kőkortól a honfoglalásig. Budapest.

Wengrow, D. 2001: The evolution of simplicity: aesthetic labour and social change in the Neolithic Near East. In: Gosden, C. (ed.): Archaeology and Aesthetics. World Archaeology 33, 168-188.

ZALAI-GAÁL, I. 2001: Die Gräbergruppe B2 von Mórágy-Tűzkődomb und der ältere Abschnitt der Lengyel Kultur. Acta Archaeologica Academiae Scientiarum Hungariae 52, 1-48.

ZalaI-GaÁL, I. 2002: Die neolitische Gräbergruppe B1 von Mórágy-Túzkődomb. I. Die archäologischen Funde und Befunde. Szekszárd-Sawarbrücken.

Zalai-GaÁL, I. 2008: An der Wende vom Neolithikum zur Kupferzeit in Transdanubien (Ungarn): Die „Häuptlingsgräber” der Lengyel-Kultur in Alsónyék-Kanizsa-dűlol. Das Altertum 53, 241-280.

ZalaI-GAÁl, I., 2010: Die soziale Differenzierung im Spätneolithikum Südtransdanubiens. Varia Archaeologica Hungarica 24, Archaeolingua, Budapest.

ZeEb-Lanz, A. 2003: Keramikverzierungsstil als Kommunikationsmittel: Ein Beispiel aus dem frühen Jungneolithikum Südwestdeutschlands. In: Veit, U. - Kienlin, T. L. - Kümmel, C. - SAscha, S. (Hrsg.): Spuren und Botschaften: Interpretationen materieller Kultur. Tübinger Archäologische Taschenbücher 4. Münster-New York, 245-264.

ZeEB-LANZ, A. 2006: Überlegungen zur Sozialaspekten keramischer Guppen. Beispiele aus der Neolithikum Südwestdeutschlands. In: Burmeister, St. - Müller-Scheessel, N. (Hrsg): Soziale Gruppen - kulturelle Grenzen. Die Interpretation sozialer Identitäten in der prähistorischen Archäologie. Tübingen Archäologischen Taschenbücher 5, Münster, 81-102. 